ECPS Party Profile Series 鼠
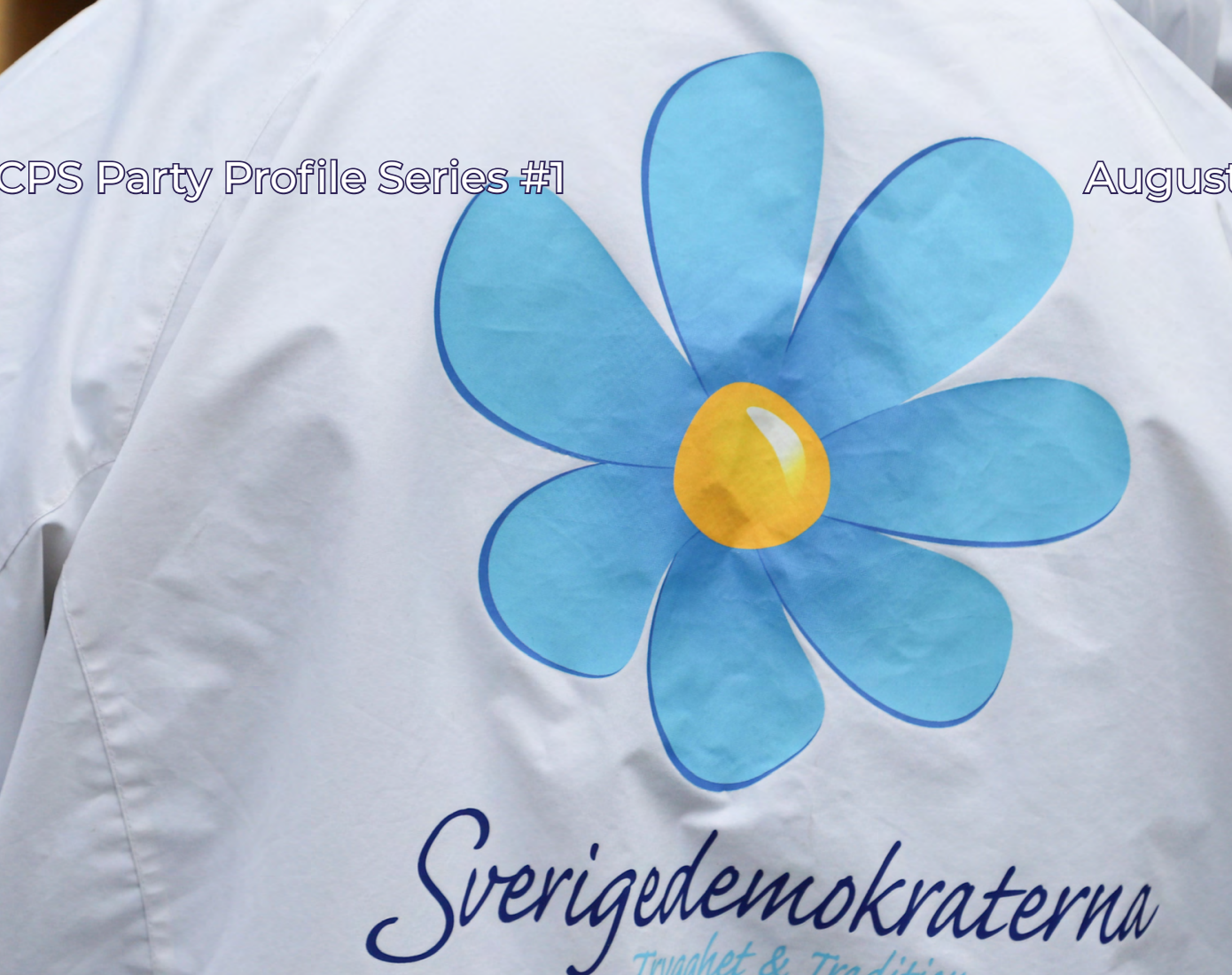

Sverigedemokraterna

AUTHOR: Bulent Kenes

The Sweden Democrats: Killer of Swedish Exceptionalism

\title{
ECPS
}




\section{The Sweden Democrats: Killer of Swedish Exceptionalism}

BY BULENT KENES

\section{ABSTRACT}

Like all liberal democracies, Sweden also faces challenges associated with globalization, international migration, and growing inequality. Despite its reputation as a moral superpower, Sweden is not immune to racism, nationalism, xenophobia, Islamophobia, and anti-immigrant sentiment. Sweden Democrats (SD), which originated from an extreme right-wing milieu, represents populist radical-right in Sweden. Since the party had its roots in Swedish fascism and white nationalism, the SD has failed to present a respectable façade so far.

BULENT KENES is an academic and a journalist who has over 25 years of professional experience. He has managed multiple publications, both in Turkish and English.

ECPS Leader Profile Series offer analyses of political leaders and prominent public figures with populist tendencies. Unless otherwise indicated, the views expressed by the author are only attributable him and not to any institution with which they are associated.

The profile available for free downloading from the ECPS website (www. populismstudies.org)

CECPS 2021 


\section{Table of contents}

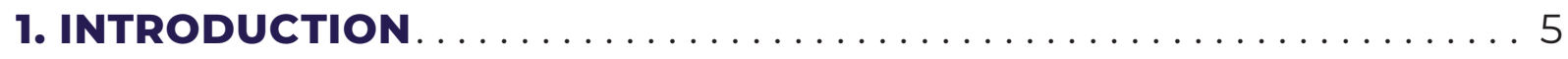

2. THE SD FOUNDED OVER NEO-NAZI GROUND $\ldots \ldots \ldots \ldots \ldots \ldots 7$

3. THE SD HAS BECOME A NEW SHELTER FOR THE WORKING CLASS.

4. RACISM \& XENOPHOBIA: THE SD'S TWO MAIN CHARACTERISTICS TO HIDE.

5. BETWEEN CULTURAL RACISM AND CARE RACISM

6. IMMIGRANTS: FROM “GUEST WORKERS" TO "FUEL FOR THE SD"

7. IMMIGRANTS: APPROACHING DOOM, DECAY, ENEMIES, AND THREATS

8. MUSLIMS AS A "UNIVERSAL OUT-GROUP," ISLAM AS AN "OPEN THREAT" 
11. THE SD FOLLOW THE LINE OF OTHER PRR PARTIES:

EUROSCEPTICISM

CONCLUSION ...................................... 35

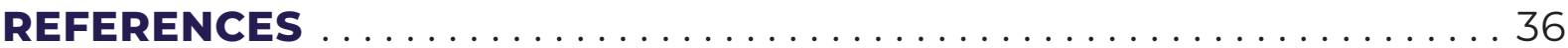




\section{INTRODUCTION}

Like many regions around the world, Europe has witnessed a resurgence of populist, radical-right (PRR) parties over the past three decades. These parties share an emphasis on ethno-nationalism, and their programs are directed toward making the nation more ethnically homogeneous. They also tend to accuse elites of favoring internationalism and cosmopolitanism over the nation and of putting their own interests ahead of the interests of the people (Rydgren \& van der Meiden, 2019). Hence, the core message of PRR parties is a mixture of ethnic nationalism (nativism), authoritarianism, and populism (Mudde 2007).

Nativism, which overlaps with the boundaries of the modern state and those of the native ethnic majority population (Norocel, 2017), is defined as "an ideology, which holds that states should be inhabited exclusively by members of the native group ('the nation') and that non-native elements are fundamentally threatening to the ethnic purity and the homogenous nation-state" (Mudde, 2007; Norocel, 2017). This feature is related to the protection of national values and traditions, welfare chauvinism, and opposition to immigration, Islam, and the European Union (EU) (Backlund \& Jungar, 2019). Authoritarianism pertains to a punitive interpretation of conventional ethics coupled with a strict enforcement of law and order (Norris, 2005) in which infringements of authority are to be punished severely (Mudde, 2007). This feature most notably relates to an uncompromising approach to combatting crime and terrorism. Meanwhile, populism is understood as a "vision of democracy" that favors the fulfilment of the unmediated will of the people (Backlund \& Jungar, 2019).

PRR parties usually mobilize support by their claiming that mainstream political parties are unresponsive to the voters' demands, together with a promise to bridge the gap between the people and the political establishment by providing voters with neglected policy alternatives (Mudde \& Kaltwasser, 2012). In this context, the PRR vote has been driven mainly by policy concerns, primarily on the issue of immigration (Backlund \& Jungar, 2019). Despite immigration having been a political concern agenda in Sweden for decades, the country was exceptional for lacking a PRR party in parliament until the beginning of last decade. With the partial exception of the 1991 election, when the newly formed New Democracy garnered 6.7 percent of the vote but did not get re-elected in 1994 and dissolved shortly thereafter (Taggart, 1996), no Swedish radical right-wing party had come close to winning a parliamentary seat until the 2010 election (Rydgren \& van der Meiden, 2019).

The political sociologist Rydgren (2002) posited four main explanations for why Sweden was exceptional in regards to PRR parties: i) Social class still mattered more in Sweden than elsewhere; ii) Partly as a result of this, socio-economic issues still structured most politics in Sweden, and issues 
belonging to the sociocultural dimension - most importantly immigration - were of low salience to the voters; iii) There was a relatively low degree of convergence between the major mainstream parties, and voters still perceived clear policy alternatives across the left-right divide; and iv) The leading radical right-wing alternative, the Sweden Democrats (Sverigedemokraterna, SD), was perceived as being too extreme (Rydgren, 2002). Compared to its Nordic neighbors, the realignment process in Sweden was delayed. Socioeconomic politics still dominated the agenda, and voters prioritized these over sociocultural political issues. Although class voting declined slowly in Sweden, it remained fairly high throughout the 1990s and early 2000s, especially among the working classes. However, this has begun to change in the 2010s (Rydgren \& van der Meiden, 2019). 


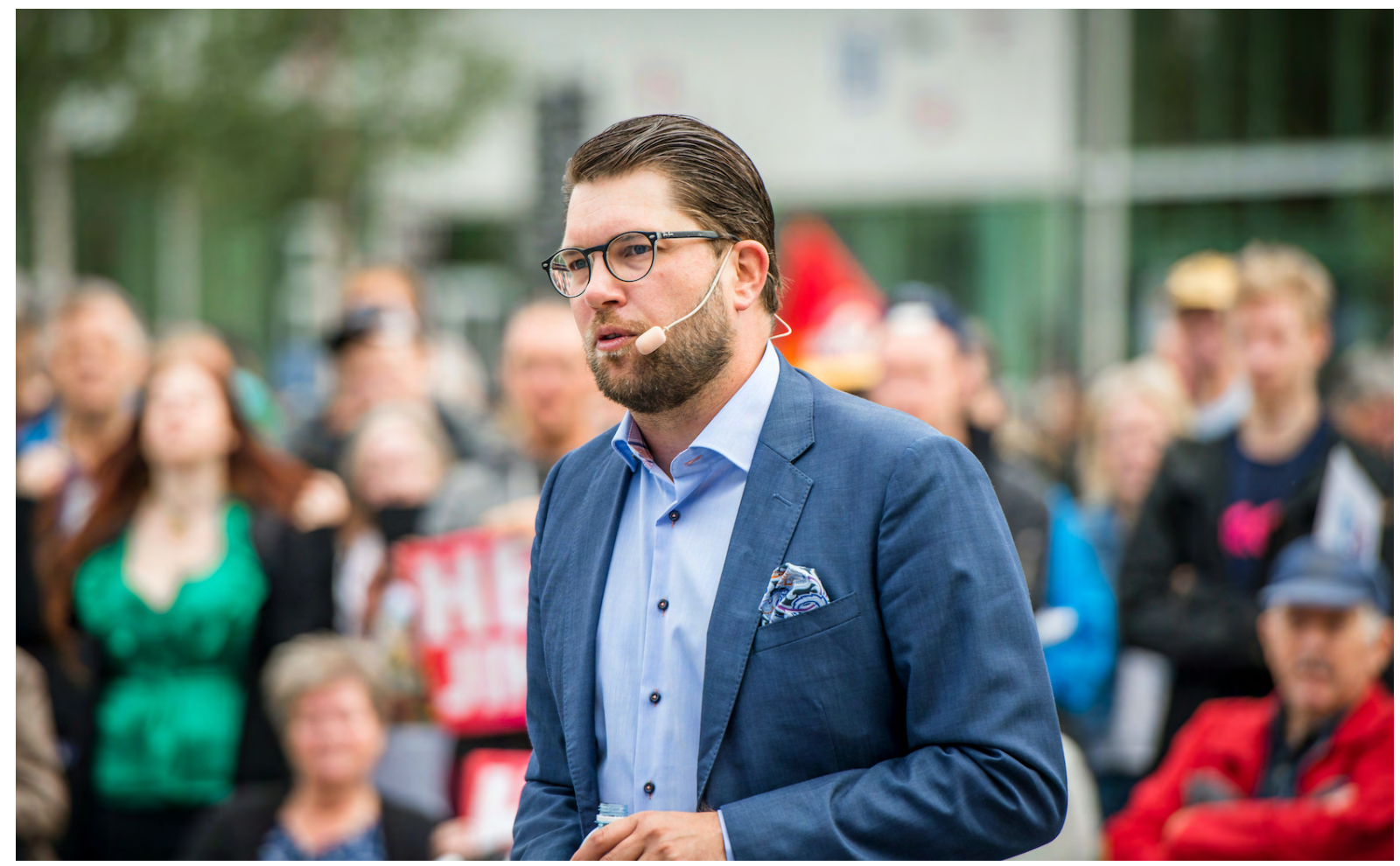

Sweden Democrats' Square Meeting in Umeå. Jimmie Åkesson speaks to the people on the city square where opposition left-wingers have formed a chain and protest in Umeå, Sweden on August 14, 2018.

\section{The SD Founded Over Neo-Nazi Ground}

The SD was founded in 1988 (Rydgren, 2006) as a successor to The Sweden Party (Sverigepartiet), which was founded in 1986 as a result of the merger between the Progress Party (Framstegspartiet) and the racist and far-right political group Keep Sweden Swedish (Bevara Sverige Svenskt) (Jungar \& Jupskås 2014; Elgenius \& Rydgren 2019). The SD originated from an extreme right-wing milieu and was long viewed as morally and politically illegitimate by a large segment of voters and by mainstream parties. Since the party originally had its roots in Swedish fascism (Rydgren, 2006) and white nationalism (Rothwell, 2018), the SD failed to present a respectable façade (Peterson 2016; Rydgren 2002).

The SD's ambivalent relationship to neo-Nazis and other openly right-wing extremists has been a recurrent problem for the party. During the first half of the 1990s, the boundaries between these groups and the SD were blurred. Around the mid1990s, the new party leadership banned political uniforms at SD demonstrations (Rydgren \& van der Meiden, 2019). The SD began a process of transformation as it sought to become a democratically legitimate party; however, success at the polls was not immediate. The SD struggled to gain traction in part because of the nationalist-populist party New Democracy (NyD), with its political rhetoric based on an anti-establishment, anti-immigration, anti-taxes and anti-bureaucracy worldview (Westlind, 1996). There was little space for the SD to consolidate its position in Swedish politics. Even though NyD more or less dissolved during the 1994 general elections, the SD was unable to attract more than 14,000 votes (Hellström \& Nilsson, 2010).

Despite its efforts at legitimization, it was still not uncommon to find SD activists who had connections to neo-Nazi environments, including members in relatively prominent positions. The party has increasingly tried to distance itself from the extra-parliamentary extreme right. These efforts began when one of the party's hard-line factions left the party to form the National Democrats. Ahead 
of the 2002 election, the SD managed to recruit the Conservative party deputy Sten Christer Andersson to join the party; this signaled an increased legitimacy. However, the SD still received only 1.4 percent of the votes in the 2002 election (Rydgren \& van der Meiden, 2019).

During the 2000s the SD's so-called "Scania gang" - also known as the "Gang of Four" and which consisted of the youth wing chair Jimmie Åkesson, Björn Söder, Mattias Karlsson, and Richard Jomshof continued and expanded the SD's moderation policy, which included ousting openly extremist members and reshaping the SD's platform. In 2003, the party declared the Universal Declaration of Human Rights to be a cornerstone of its policies (Rydgren, 2006). In 2005, Åkesson defeated Mikael Jansson in a leadership contest. Shortly after, the party changed its logo from the flaming torch to one featuring an Anemone hepatica, reminiscent of the party's very first, but short-lived logo (Sweden Democrats, 2005).

Efforts at creating a more credible image intensified after Åkesson assumed leadership of the party and may have contributed to the party's relative success in the 2006 election, in which the SD managed to increase its voter share to almost 3 percent. When the SD entered Parliament with 5.7 percent of the votes in 2010 , Sweden was no longer exceptional in not having had an electorally successful PRR party (Rydgren \& van der Meiden, 2019). Immigration and law \& order were the two most important issues for voters who cast their ballot for the SD in the 2010 elections according to an electoral survey conducted by Swedish public television (SVT) (Holmberg et al, 2010).

The political mainstream and media's reaction against the success of the SD was one of profound shock. Nevertheless, most commentators were, in general, careful not to blame the voters. A strong faith in rationality was reflected in the texts, in the sense that voters were considered to be rational but not racists; therefore, they must have had other reasons for voting SD (Hellström \& Nilsson, 2010). The election result was also interpreted as precipitating: i) The decline of class politics in Sweden; ii) The growing salience of

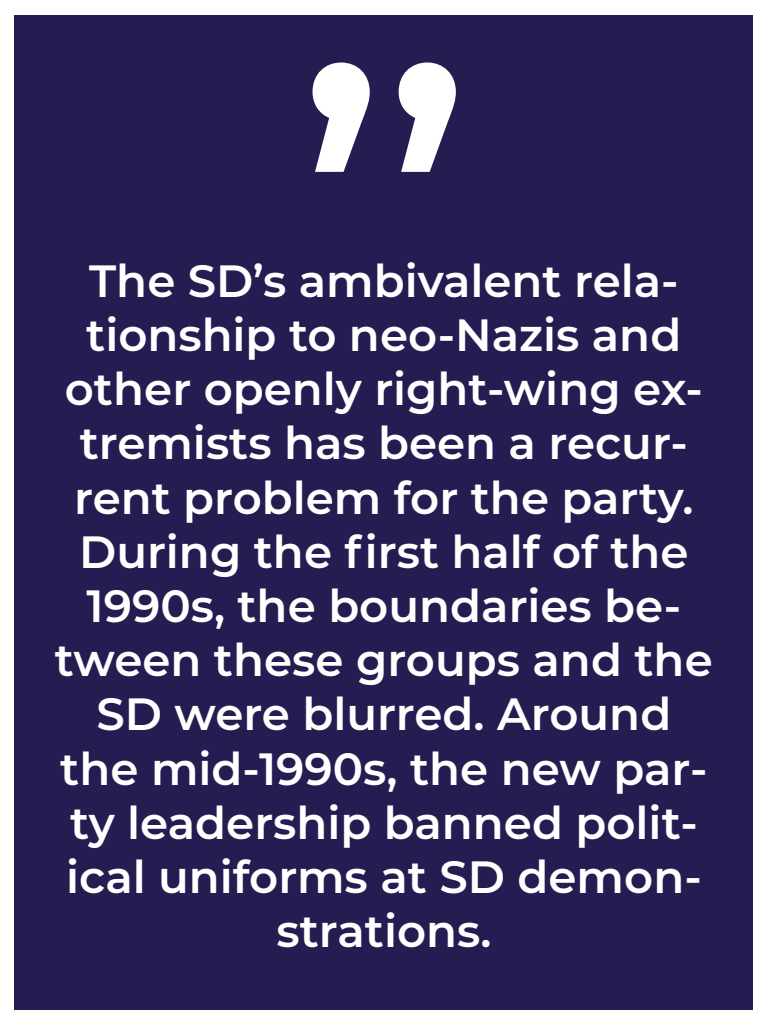

sociocultural politics, and in particular the politicization of the immigration issue; iii) The increased convergence caused by a double move toward the center by the Social Democratic party and the Conservative Party, leaving voters confused about policy alternatives; iv) The successful process by which the SD tried to distance itself from its neo-fascist past and erect a more respectable façade.

The decline of class voting has been explained by major societal changes - e.g., modernization and globalization - and increased educational levels as well as to changes in people's value structures. The overall left-right polarization in the Swedish party system also seems to affect class voting (Jansen et al. 2012), meaning that ideological convergence between mainstream parties may decrease class voting as well. As social democratic parties move toward the center in order to win middle-class voters, the effect may be weakened alignments with working-class voters. In addition, the position of social democratic parties on sociocultural issues influences class voting: as these parties increasingly tried to mobilize based on left-liberal sociocultural policies that were predominantly embraced by the new middle classes, they may have alienated some working-class voters who on aver- 
age share more traditional and authoritarian values (Kitschelt, 2012). In any case, a decrease in left-right distinctions leaves room for other cleavages to be politicized (Rydgren \& van der Meiden, 2019).

At the same time, trade union membership has declined in Sweden since the beginning of 1990s. In 2015, 71 percent of all employees were members of a trade union, and the share among workers was 65 percent. Twenty years earlier, 88 percent of all workers were union members (Larsson, 2015). This decline is important, since the support for PRR parties tends to be higher among non-unionized workers than among unionized working-class voters (Rydgren \& van der Meiden, 2019). Nevertheless, 24 percent of unionized working-class voters supported the SD in 2015, making it the second most popular party among this voting bloc (SCB, 2015).

As is the case for most PRR parties in most other European countries, the SD receives its strongest support from the established working class, in spite of the high degree of class voting and left-right mobilization which used to characterize Swedish politics (Oskarson \& Demker, 2015). Several studies point to social marginalization and economic risk exposure as important determinants for working-class support for PRR parties, linked to a model of globalization where a group of "losers" competes against a group of "winners" (Betz, 2004 \& Rydgren, 2007). Due to modernization and globalization, people in low-skilled jobs or in traditional sectors and with low levels of educational attainment risk losing out when competition for jobs and resources becomes global due to open borders and migration (Oskarson \& Demker, 2015). These workers - those excluded from the transition toward a knowledge and service society - have been successfully recruited by PRR parties (Oesch, 2008).

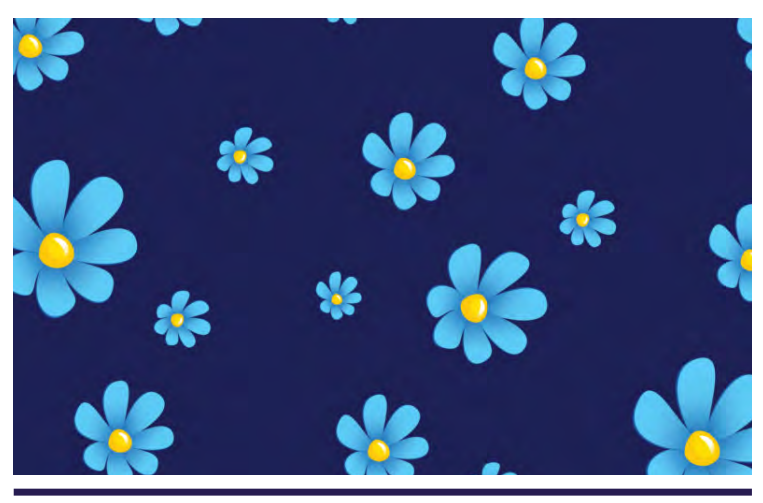

\section{The SD Has Become a New Shelter for the Working Class}

Moreover, the lower educated and unemployed are more likely to vote for xenophobic PRR parties. Many studies have found strong correlations between low levels of education and support for nationalist PRR parties, along with more authoritarian ideological leanings (Hainmueller \& Hiscox, 2007). As education is very closely associated with class position, this could indicate that the critical factor behind working-class support for PRR parties isn't class but education (Ivarsflaten \& Stubager, 2013).

This pattern holds true in Sweden (Holmberg, 2007). Class differences as well as authoritarian leanings can largely be explained by differences in education (Bengtsson et al., 2013). As a result, two-thirds of the total support for the SD came from the working class, of which 28 percent came from the "lower technical" and 27 percent from the "lower sales and service" categories. In comparison, the Social Democrats received just over half (51 percent) of their votes from the working class (Oskarson \& Demker, 2015).

Meanwhile, Swedish election data shows that layoff notifications among lowskilled native-born workers account for 31 percent of the increased vote share for the SD. The effect of layoff notifications on support for the SD is larger in areas with a high share of low-skilled immigrants and in areas with a low share of high-skilled immigrants. These findings are in line with theories suggesting that voters at- 
tribute their impaired economic status to immigration. For every second low-skilled native-born worker receiving a layoff notification, the SD gains, on average, one additional vote (Dehdari, 2018).

The SD has refused to situate itself on the left-right scale (Heinö, 2016) in the hopes of cherry-picking conflicting policies from both left and right (Timbro, 2019). This has allowed them to scoop up voters as the Swedish working class has de-aligned with the Social Democratic Party. In this dealignment, the SD saw an opportunity to mobilize underlying authoritarian ideological leanings and political distrust.

These social cleavages present possible explanations for the labor class's support of populist/nationalist parties like the SD. A first line of explanation sees working-class support of PRR parties as an expression of economic conflict in terms of competition with immigrants in the labor market (Oskarson \& Demker, 2015). A second line of explanation focuses on the nationalist/traditionalist aspect of the parties and explains working-class support more in terms of a defense of traditionalist and authoritarian values (Napier \& Jost, 2008). A third line of explanation sees the populist/nationalist parties as protest parties, opposing the "political establishment" in defense of "ordinary people"; this line of thought focuses more on the anti-political or anti-elite aspect of the parties (Abedi, 2004).

As it was mentioned above, another contributing factor to the success of PRR parties is the political opportunities that arise from the convergence of mainstream parties in political space (Kitschelt, 1995). When Swedish voters are asked, the overall left-right distance between the Social Democrats and the Conservatives was perceived to be larger in the 1970s than in more recent elections. The tendency of convergence is clearly visible and in the creation of the center-right electoral coalition, the Alliance (Alliansen) (Rydgren \& van der Meiden, 2019). As left-right polarization in the traditional Swedish party system has decreased and most parties have moved towards a libertarian position, it has become possible to articulate an authoritarian ideological position, which the
SD has done (Oskarson \& Demker, 2015).

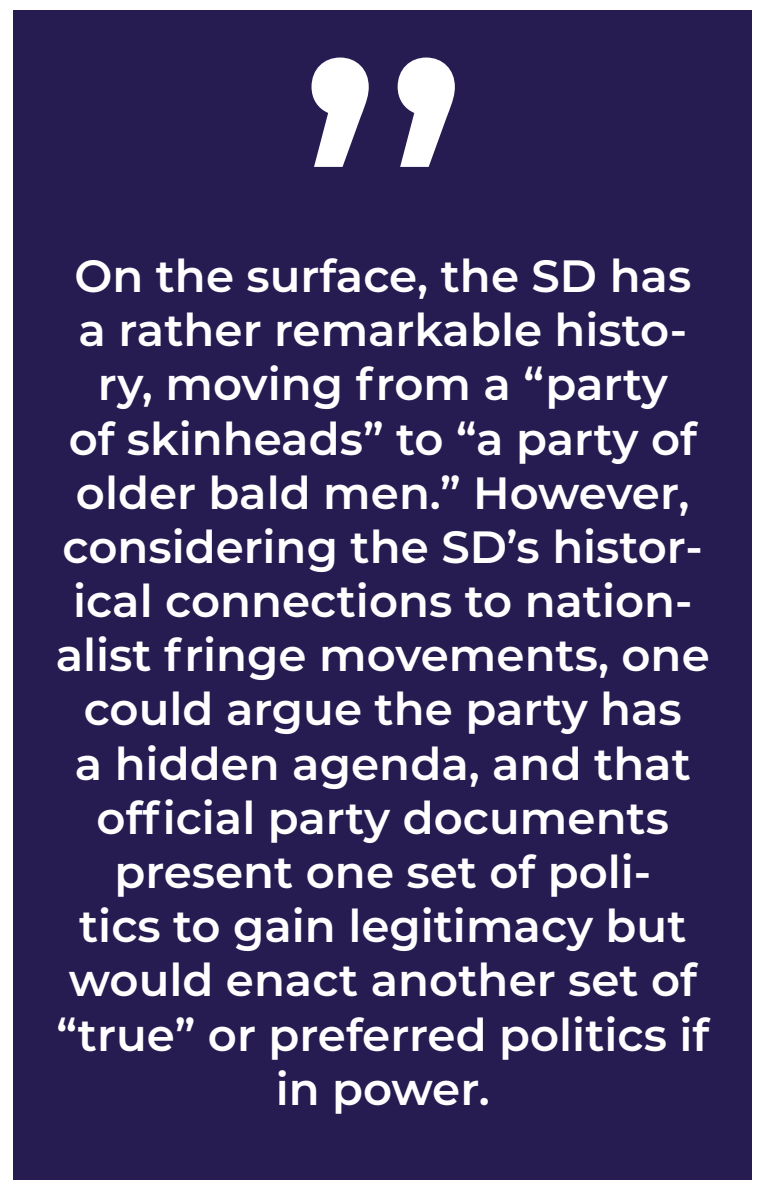

Meanwhile, the SD officially changed its designation from nationalist to social conservative in 2011 , and in 2012 , the party introduced what it called "zero tolerance for racism," which resulted in numerous expulsions of party members who had publicly expressed opinions deemed too racist (Widfeldt 2015). The SD has managed to quite radically transform their image in a democratically legitimate and credible direction. Thus, while the party in its early days was dismissed as consisting of racist criminals and hooligans, scholars and political commentators currently include the SD in the Western European family of new PRR parties (Strömblad \& Malmberg, 2016). Nevertheless, one may argue that these expulsions were primarily cosmetic and designed to signal to voters that the SD had a serious desire to rid itself of its politically extreme past. These efforts likely helped to destigmatize the party in the eyes of many voters (Rydgren \& van der Meiden, 2019).

On the surface, the SD has a rather re- 
markable history, moving from a "party of skinheads" to "a party of older bald men." Survey data also shows that SD voters now tend to articulate rather mainstream opinions with regard to welfare policy, taxation, and so forth (Holmberg, 2007). However, qualitative assessments by experts estimate radical parties as being more extreme than their actual policies would suggest (Klingemann et al, 2006; Benoit \& Laver 2006; Volkens, 2007), while supporters of radical parties tend to be less moderate than the parties themselves (Klingemann et al, 2006). Considering the SD's historical connections to nationalist fringe movements, one could argue the party has a hidden agenda, and that official party documents present one set of politics to gain legitimacy but would enact another set of "true" or preferred politics if in power (Backlund, 2011).

In the 2014 election, 12.9 percent of voters supported the SD (Elgenius \& Rydgren 2019) despite the party being characterized as right-wing populist (Berezin, 2013), national-conservative, anti-immigrant, and far-right (Downs, 2012). Since this election, the SD has played a huge role in Swedish politics (Heinö, 2016). The party's fortunes have continued to rise, and the SD enjoyed increased support in the 2018 general election, when it garnered 17.5 percent of all votes and secured 62 seats in Parliament, becoming Sweden's third largest party (Deutsche Welle, 2018).

Thus, the SD has increased its support in every election since its formation. There is no other party in Europe, regardless of political affiliation, that has had the same kind of success. The SD's success has created a rift within the formerly solid center-right alliance (Timbro, 2019). And while there is a popular perception that PRR parties draw support from the very young or the very old, SD voters are over-represented among middle-aged people. As the party's popularity has grown, the typical SD-voter tends to be married, have a fairly strong household income, and live in an area that could be regarded as middle-class suburbia (Sannerstedt, 2008). 


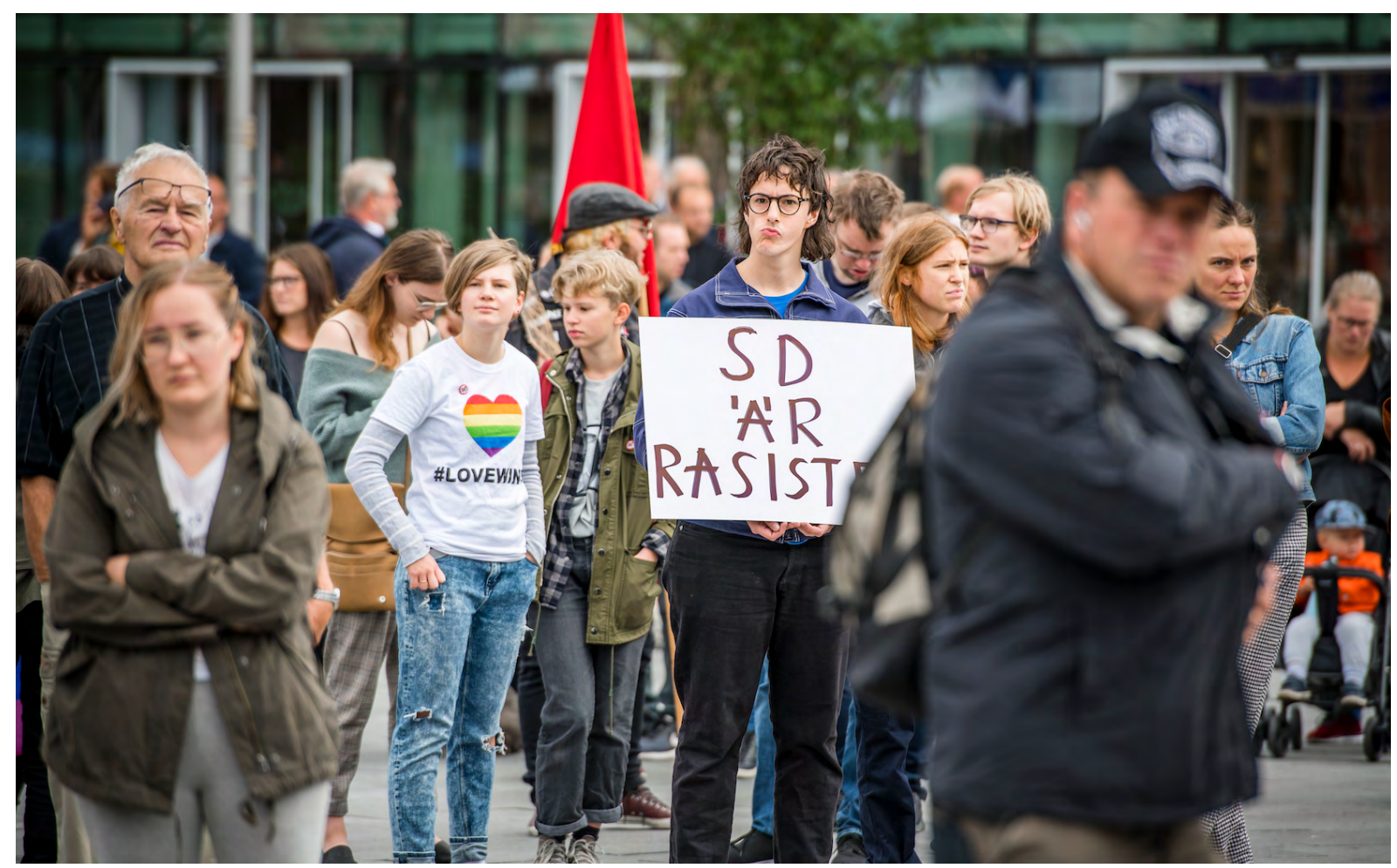

Jimmie Åkesson speaks to the people on the city square where opposition left-wingers have formed a chain and protest in Umeå, Sweden on August 14, 2018.

\section{Racism \&}

\section{Xenophobia: The SD's Two Main}

\section{Characteristics to} Hide

The SD held its first annual meeting in 1989 and elected Anders Klarström as the party's president. Prior to this, Klarström had been a member of a neo-Nazi party (Nordiska Rikspartiet) and had a criminal record that included the stealing of ammunition, vandalism, and making illegal threats (Hellström \& Nilsson, 2010). The SD's first auditor, Gustaf Ekström, was a Waffen-SS veteran and had been a member of the national socialist party Svensk Socialistisk Samling in the 1940s (Widfeldt, 2010). In 1989, Ekström became a member of the SD's national board. Other representatives of the party's executive members had similar backgrounds. Some were members of violent extreme right movements such as the White Arian Resistance (Vitt Ariskt Motstånd) and Keep Sweden
Swedish (Bevara Sverige Svenskt) (Hellström \& Nilsson, 2010).

Furthermore, some SD members have been involved in the growing industry of white power music and have sponsored music of the nationalist Viking rock band Ultima Thule. Various party officials have acknowledged that being fans of Ultima Thule's music factored prominently in their decision to become politically engaged (Teitelbaum, 2013). And early in its existence, the SD recommended international connections to its members. These included the National Democratic Party of Germany, the American National Association for the Advancement of White People, and publications like the Nazi Nation Europa and Nouvelle École, a newspaper that advocates racial biology (Expo, 2014). In its members' bulletin of 1989, the party also published a list of addresses of allies, i.e. the Front National in France, pro-apartheid newspapers in South Africa, a Ku Klux Klan affiliated journal in the US, and the journal Spearhead, published by the notorious neo-Nazi John Tydall in England. The SD's logo from the 1990s until 2006 was a version of the torch used by the British National Front (Hellström \& Nilsson, 2010; Larsson \& Ekman 2001). 
In the mid-1990s, the SD continued to attract members known to be associated with riots and Nazi groups, and the party continued its racist, extremist activities. For instance, SD organized a gathering in Stockholm on November 30, 1993, to celebrate the late king of Sweden, Karl XII. Approximately 1,000 people took part in the event, which ended in chaos and violence. At the front, the Nazi flag hung beside the Swedish flag. The entire city-center resonated with the crowd's shouts of "Sieg Heil" (Tamas, 2003).

In 1995, the newly elected party president Mikael Jansson decided to bar extremists from the party and prohibited the wearing of uniforms during demonstrations. However, prior to the elections in 1998, the party did not hesitate to receive financial support from the French Front National of Jean Marie Le Pen and joined forces with the European nationalist network (Euro-Nat) (Hellström \& Nilsson, 2010).

But by the end of the decade, the party took further steps to moderate itself. In 1999, the SD left Euro-Nat although the youth wing remained affiliated until 2002 (Expo, 2010). In 2001, the most extreme faction was expelled from the SD, leading to the formation of the more radical $\mathrm{Na}$ tional Democrats (Rydgren, 2006).

Some academicians, like Castells, attribute the emergence and rise of PRR parties like SD with the cultural identity crisis rocking European societies. According to him, supra-nationality leads to national identities becoming blurred and major cities getting more entangled. In this age of information overflow, people who feel insecure about who they are may turn to nationalist ideologies as a collectivist response to the neo-liberalization of the world (Castells, 1993). As such, there has been an upsurge in research on xenophobic populist or PRR parties during the last decades, mirroring their political successes. In the Swedish context, a country characterized by neoliberal restructuring has seen debates on issues of "race," citizenship, and belonging. The tendency to define racism in terms of biological racism continues to be strong in Sweden. Instead of using the word "racism," researchers often talk about migration sceptics, anti-mi- gration, welfare-chauvinism, nativism, and xenophobia (Mulinari, et al. 2014) as issues defining the SD.

Many argue that traditional racism has lost much of its power in Western Europe and a new type of racism has emerged post-WWII (Barker, 1981 \& Miles, 1989). This new form of racism is not based on biology and hierarchies, but on culture and difference. It does not argue that some races are superior or inferior, but rather stresses the insurmountable difference between culturally defined entities. According to the new cultural racism, a merging of different ethnic groups would lead to the abolition of the unique qualities that constitute the ethnicities, implying that different ethnic groups should be kept separated (Rydgren, 2008).

In this context, Teitelbaum has called the SD a radical nationalist party (Teitelbaum, 2013), and the party has been described by Rydgren and others as xenophobic, racist, and right-wing populist (Rydgren, 2008 \& Mudde, 2007). In 2013 a Sveriges Radio journalist called the SD xenophobic, which resulted in a complaint lodged with the broadcasting regulator. The Swedish Broadcasting Commission determined that this description was acceptable (Mellgren, 2013).

Sociocultural authoritarianism and, more specifically, ethno-nationalism and xenophobia have been the most important niches for PRR parties seeking expanded political opportunities. (Elgenius \& Rydgren, 2019). With its emphasis on sociocultural issues, the SD's political profile is oriented to the populist radical right (PRR), at least as the concept was developed in France under the label "la Nouvelle Droite" (Declair, 1999). According to the official party doctrine, Swedishness is constituted by culture and not by race. The SD has switched its focus from ethnicity to an emphasis on culture and impermeable cultural differences (Hellström \& Nilsson, 2010). The SD does not presuppose either that certain ethnic groups or cultures are superior or inferior to others, but rather holds that the difference between Swedes and non-Swedes is considered incommensurable. In this view, sometimes referred to as ethno-pluralism (Rydgren, 2007), all people are natural- 
ly attached to separate ethnic enclaves (Hellström \& Nilsson, 2010).

Accordingly, the SD depicts multiculturalism as the source of all evil without denying other peoples' right to reside in distinct cultural enclaves: "The party distances itself from multiculturalism, racism, and doctrines that predict ethnic origin to be the only determinant for national belonging" (Sverigedemokraterna, 2008). The SD argues that multiculturalism poses a threat to the shared values that constitute the cultural community of Sweden. The party defines what it means by Swedish identity: "Swedish applies to the one who has a principal Swedish identity and is from her own perspective and by others regarded as Swedish." The rhetorical figure underpinning this message is: "Sweden belongs to the Swedes" (Hellström \& Nilsson, 2010). Taking this into account, it is a reasonable assumption to say that many immigration-sceptic SD voters are also xenophobes - and that some of them are also racists (Rydgren, 2008).

The SD has shifted its ideological role models over time. Initially, the party was modelled after neo-right proponents (e.g. Le Pen and Haider); but now, it models itself after leading Social Democratic figures. In its rhetoric, the SD adheres to the more traditional version of Social Democracy. Its position could thus be summarized as, "We are the true Social Democrats." In this context, the SD returns to Per-Albin Hansson (Swedish Prime Minister between 1932 and 1946) as a key inspiration for its politics. Hansson is regarded as the chief architect of the transformation of post-war Sweden to a "people's home" (folkhemmet). In the 19th century, this metaphor was associated with the ideals of organic conservatism and nationalist romanticism (Hall, 1998), although since 1932, the "people's home" has been used as a mobilizing metaphor for the Social Democratic project of administrating and realizing social reforms.

The folkhem is the quintessential concept of modern Swedish politics and society, representing a political and social project aimed at symbolically gathering together Swedish men and women under the protective roof of a collective home
(Andersson, 2009). The concept embodies the "Swedish model," a social-democratic welfare system that couples comprehensive welfare with democratic government on egalitarian principles under the stewardship of social-democratic governance. It specifically references the period 1932-

76, when the Social Democrats governed Sweden. As a political concept its meanings have shifted over time This metaphor is now employed by the SD to summarize its nostalgic political vision of a homogeneous political system for all Swedish people. It is also a strategy of good-by-association(Hellström \& Nilsson, 2010). Today, the SD claims to be the folkhem's sole guardian (Norocel, 2017).

According to Norocel, the SD has exploited the folkhem's conceptual salience to cement an image of Swedish society as the home reserved exclusively for "Swedish people" who are under constant threat at the hands of immediate "others." Indeed, research evinces that such welfare chauvinist appeals were used to

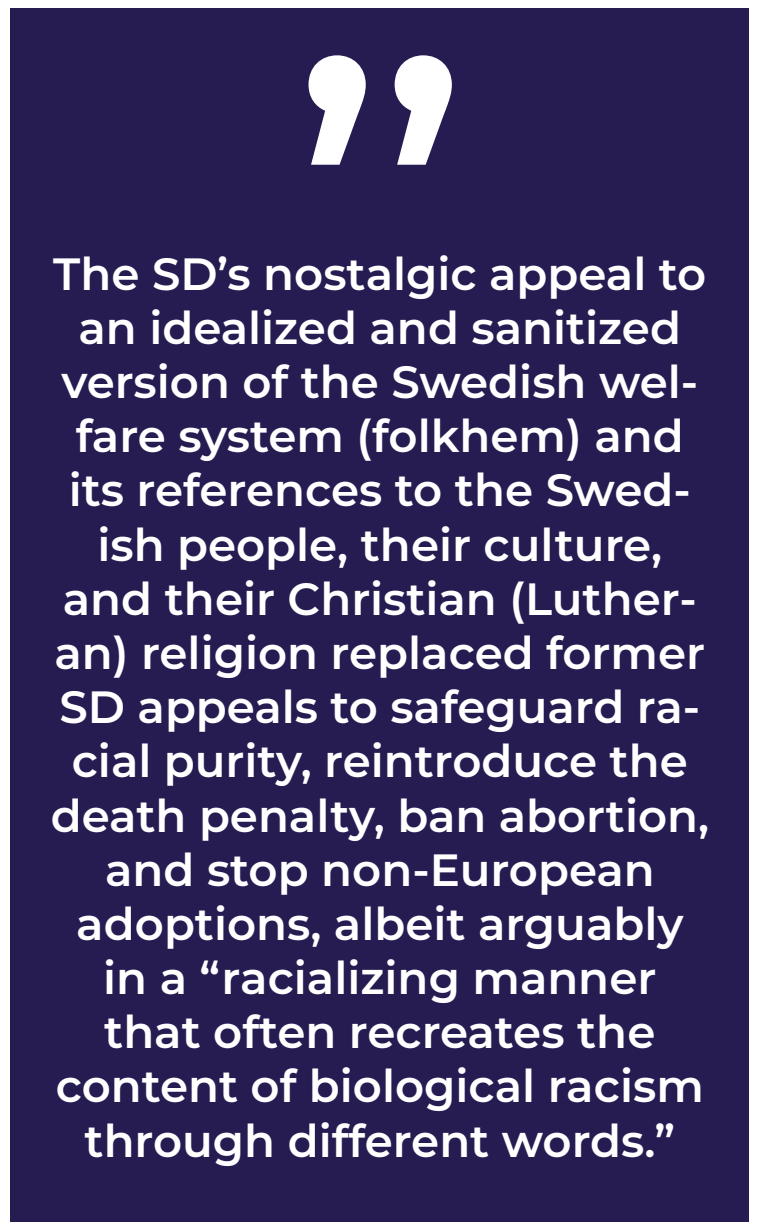


consolidate the SD's ideological profile in its struggle for political legitimacy, in its confrontations with other Swedish Parliamentary parties, in its mediated interactions in Swedish mainstream media, and in its attempts to distil cultural racism into a rhetoric of care for their own ethnic group (Norocel, 2017).

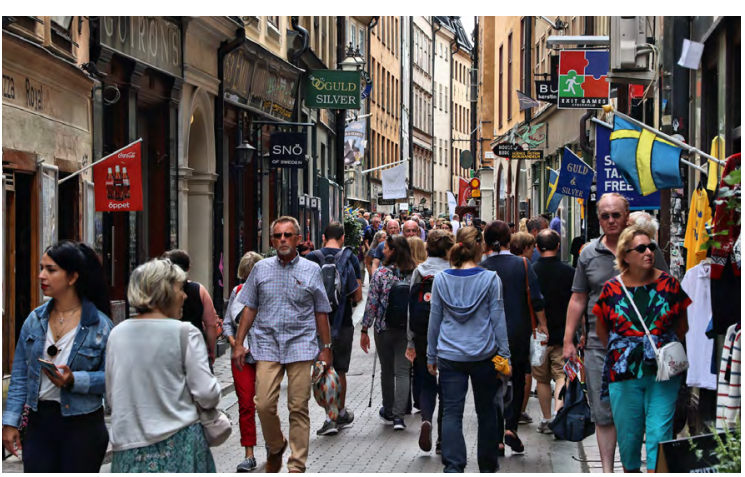

People shop in Gamla Stan (Old Town) in Stockholm, Sweden on August 23, 2018

\section{Between Cultural Racism and Care Racism}

SD leader Jimmie Åkesson's speeches at Almedalen Week, an annual event taking place in Almedalen, a park on Gotland, consolidated an idealized vision of the folkhem as an exemplary welfare society based on the homogeneous national community of Swedish citizens. In doing so, Åkesson emphasized that the SD's politics are about "unity and consensus, about a coherent, warm ... Sweden"; and about a tightly knit society that makes no distinctions "between the privileged or the neglected; there are no sweethearts and no stepchildren. Not one of them despises the other."

In other words, the folkhem envisaged by Åkesson is one built on the ethnic and cultural homogeneity of the Swedish native majority, engaged in an intimate relationship characterized by warmth and solidarity towards one another, in a manner resembling a family united under the folkhem's protective roof. By describing the folkhem's inhabitants as family members, Åkesson attempted to enforce the idea that the Swedish native majority constitutes a homogeneous community of blood (Norocel, 2017).

In other words, the SD's nostalgic appeal to an idealized and sanitized version of the Swedish welfare system (folkhem) (Hellström, Nilsson, \& Stoltz, 2012) and its references to the Swedish people, their culture, and their Christian (Lutheran) religion replaced former SD appeals to safeguard racial purity, reintroduce the death penalty, ban abortion, and stop non-European adoptions, albeit arguably in a "racializing manner that often recreates the content of biological racism through different words" (Mulinari \& Neergaard, 2014).

Mulinari et al. define the SD as a culturally racist party. One central feature of cultural racism is that racism is increasingly expressed in ways that do not use the word "race." Instead, ethnicity, culture, and religion are used in a racializing manner that often recreates the content of biological racism through different words. This cultural racism, they argue, characterizes the SD, which reproduces and develops hierarchies between groups that are already established. The radical nature of the SD lies in how they present solutions and, through these solutions, develop their variant of racism. Their contention is that the hegemonic Swedish public and political discourse already contains similar racist elements, in moderate forms (Mulinari, Neergaard, Lewis, Kennedy-Macfoy, 2014 \& Hellström and Nilsson, 2010).

Mulinari et al. also highlight the concept of "care racism." According to their definition, care may be extended to the racialized other through arguing that their migration to Sweden is also bad for the migrants themselves. In this sense, care racism is formulated as helping migrants by sending them back to their "true" home. This creates two variants of care racism. The first and dominant form is caring selves, in which a racialized version of the Swedish self is constructed based on the aggregation of how the family is viewed. A second version of care racism is linked to what they see as an ethnopluralist understanding. Here caring also extends to the racialized other, albeit in the form of caring that they return to their home country, for their own good (Mulinari, 
Neergaard, Lewis, Kennedy-Macfoy, 2014).

Mulinari et al., also assert that racist parties provide an epistemic community where people care for each other. Members of racist parties use their time and resources for what they think are the common good, the caring of "their" people. Caring is the promise of the Swedish folkhem that the Social Democratic regime failed to provide. Furthermore, the SD supporters construct their exclusion and separation from the racialized other, not only as caring for the self, for our own, but also as caring for them, preserving their purity as the "other" (Mulinari, Neergaard, Lewis, Kennedy-Macfoy, 2014).

In an interview, Second Deputy Speaker of the Riksdag and then-party secretary Björn Söder elaborated on the SD party program with respect to its views on national identity by saying that he personally did not think people with dual national identities in Sweden would necessarily identify themselves as Swedish - even though an immigrant of any ethnic background in theory can become a Swedish citizen (Orrenius, 2014). Also, Teitelbaum writes that the SD is the foremost champion of cultural nationalism, or "open Swedishness." According to him, the SD's position creates a political agenda that is irreconcilable with ethno-nationalist forces. The party's cultural politics, for example, aim to encourage immigrants to embrace Swedish traditions and values. Some party members advocate for a better geographic dispersion of ethnic minorities in the country so that those minorities may more easily form a Swedish identity. He writes that the SD is a threat to ethno-nationalists as long as it pursues its assimilation agenda (Teitelbaum, 2018).

Despite there being deep ideological and political divergences between the SD and more radical nationalists, SD proponents and more radical activists can meet in the same chat forum or at the same concert of "racist music" (Deland, Hertzberg \& Hvitfeldt, 2010). Ekman and Poohl imply that culture and ideology can manifest as distinct phenomena in nationalist movements; they claim that the SD's efforts to distance themselves from National Socialists are concerns of style more than ideas (Ekman, \& Poohl, 2010).
The SD has, among all Swedish Parliamentary parties, had the largest share of elected municipal representatives resign since the 2010 elections (27.8 percent). Many of these resignations were brought on by racist statements or actions (Dagens Nyheter, 2011). This is further evidence to support the idea that today's SD is "a changed party with the same ideology," as Anna-Lena Lodenius writes (Teitelbaum, 2018). Indeed, outright racist views held by individual party members have been revealed in the media with some regularity (Bolin \& Aylott, 2019).

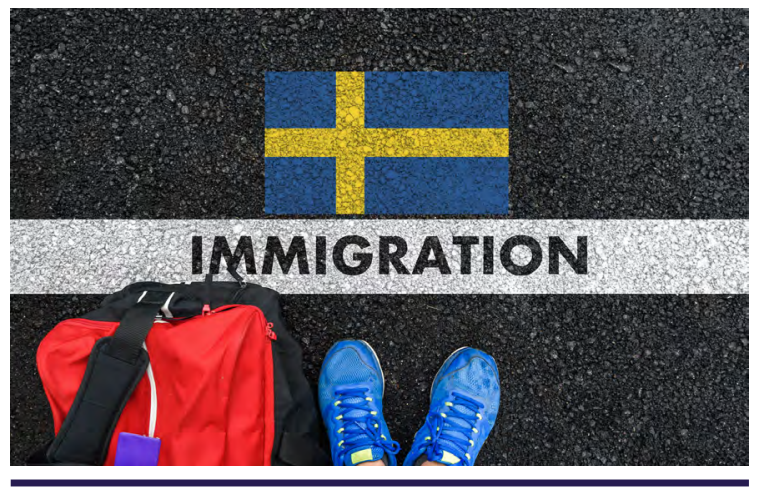

\section{Immigrants: From "Guest Workers" to "Fuel for the SD"}

Immigration has been a major source of population growth throughout Sweden's history, and since 2012, the number of immigrants to Sweden has increased while the number of emigrants has decreased. Today, about one-fifth of Sweden's population has an immigrant background (World Population Review, 2020).

Since the 1930s, Sweden has always been a country of net immigration, despite passage of the restrictive Aliens Act (the country's first immigration law) in 1927. This law remains the key piece of legislation for all aspects of migration, albeit with more recent modifications. The law's two original aims were to protect the domestic labor force from foreign job competition and, heavily informed by theories of race and eugenics, to "control immigration of peoples that do not to our benefit allow themselves to meld with our 
population." Such racialized language was later dropped, but a contradictory attitude toward immigration has been a mainstay in Swedish responses to immigrants and immigration (Skodo, 2018).

In the beginning, the Swedish state saw immigrants as temporary guest workers and assumed that they would eventually return home. Sweden began to regulate non-Nordic labor immigration in 1967, seeking to curb the arrival of guest workers and encourage those already present to leave. The economic crisis of the early 1970 s and its aftermath ended demand for foreign labor in heavy industry, bringing the era of labor immigration to a halt. However, the assumption that the guest workers would return home proved false. Not only did most stay, but they also became citizens and began to apply for family reunification visas. Ironically, the restrictive 1967 law opened a new path to immigration through such family reunification. Today, the foreign born represent 18.5 percent of Sweden's 10 million residents. Around 849,000 of all foreign born in Sweden come from Europe, while around 1 million are from non-European regions, in particular the Middle East and Asia (Skodo, 2018).

In 1975, Sweden became one of the first countries to officially adopt a policy of multiculturalism, embracing ethnic and religious diversity and state support to safeguard minority identities and culture. The state thus provided financial support for a range of activities, including state-funded minority cultural associations and mother-tongue instruction in primary schools. This policy lasted until measures were introduced in 1986 that moved Swedish integration policy away from targeting groups and toward individuals. In 1997, Sweden introduced a new integration policy according to which individual integration needs, such as employment, would be targeted (Skodo, 2018).

Meanwhile, increasing ethnic diversity has triggered different political responses in Sweden, as in many established democracies (Strömblad \& Malmberg, 2016). For instance, reflecting the stance of the $\mathrm{SD}$, Torbjörn Kastell (former party secretary) said in 2002 that the party wanted "a multicultural world, not a multicultural society" (Rydgren, 2008). Challenged by socioeconomic as well as socio-geographic cleavages, governments have searched for policy tools that may promote integration and "social cohesion" in an era of migration and globalization (Bay, Strömblad, \& Bengtsson, 2010).

Another response to increasing ethnic diversity has been the emergence of political parties that share a clearly identifiable nationalistic agenda, favoring measures to reduce immigration and strongly opposing "multicultural policies." PRR and xenophobic parties fitting such a profile are currently active in a wide array of democracies and have also managed to gain representation in a number of national parliaments (Arzheimer, 2009 \& Rydgren, 2008). Moreover, there is a longterm trend towards increasing electoral support for these political parties, at least in Western Europe (Norris, 2005).

Common denominators of xenophobic PRR parties tend to be that they have a nationalistic agenda and a highly critical and restrictive stance on issues concerning immigration and the integration of immigrants (Arzheimer, 2009 \& Norris, 2005). Like most PRR parties in Europe, the SD mobilizes support by taking a harsh stance on immigration (Ivarsflaten, 2008; Rydgren 2008, 2018). However, the party's growing strength is not due to generally increasing levels of immigration and negative attitudes among the Swedish electorate, as Swedes on average are now more tolerant towards foreigners of all kinds than in the 1990s (Oskarson \& Demker, 2015). The proportion of people who think it is a good idea to reduce the number of refugees to Sweden has decreased from 65 percent in 1992 to 40 percent in 2015 (Rydgren \& van der Meiden, 2019).

It is also a fact that the opposition to immigration and refugees among the voters of the SD is solid (Rydgren \& van der Meiden, 2019). In 2015, 93 percent of the SD's sympathizers agreed with the statement that it would be a good idea to reduce the number of refugees to Sweden. This should be compared to 42 percent of those sympathizing with the Conservative party, 29 percent of Social Democratic sympathizers, and 13 percent of those 
sympathizing with the Green Party (Demker and van der Meiden 2016).

To believe that anti-immigration attitudes are a very important factor for explaining the electoral mobilization of PRR parties makes some intuitive sense. Although the anti-immigration nexus is only a part of a wider web of issues (Mudde 1999), it is at the core of the PRR parties' political programs and dominates the images voters have of these parties. Even if not all voters who are skeptical of immigration vote for radical right-wing parties, most voters who do vote for those parties have such attitudes (Rydgren, 2008).

Nevertheless, the refugee crisis that hit Europe in 2015-16 has left a deep mark on Swedish politics. Immigration scored as one of the top issues in the 2014 and 2018 Swedish elections. Thanks to the SD's success, it has become impossible for either of the two traditional blocs to form majority governments, since neither bloc wants to govern with the support of the SD. According to Emily Schultheis, the SD won an ideological victory in the 2018 elections, as it "effectively set the terms for debate" and forced its rivals to adopt immigration policies similar to its own (Schultheis, 2018).

This new situation may prompt a structural change to Swedish parliamentarianism. The SD has already pushed the major parties to adopt far-right rhetoric, increasingly associating asylum seekers with national-security threats, terrorism, and crime. Thus, another SD policy priority, "law and order," is also linked to migration. This link is both implicit (stories of immigrant crime are often more prominent in media) and explicit (in, for example, the demand that more foreign criminals be deported) (Bolin \& Aylott, 2019). Such rhetoric in turn has led to calls to further tighten border controls and increase Sweden's ability to detain and deport asylum seekers. The electoral gains of the SD have led to the normalization of far-right migration discourse and convergence of restrictionist policies on immigration issues, including the temporary law of 2016, which received broad cross-bloc support (Skodo, 2018).

For many years, questions concerning

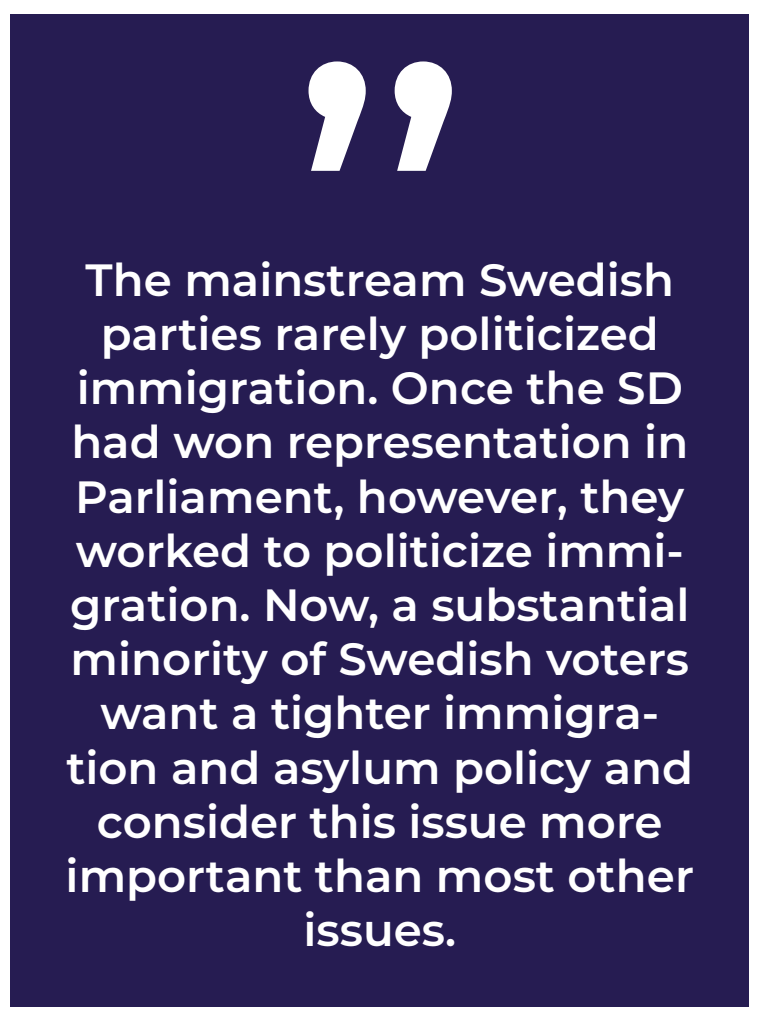

immigration were of low importance in Swedish politics. With a few exceptions, it was largely a non-issue among the political mainstream parties until 2014 (Odmalm, 2011 \& Widfeldt, 2015). However, immigration does gain importance when a political party mobilizes around the issue. In the national election of 1991, when the share of voters who thought that immigration and refugees were important issues when choosing a party increased sharply to 8 percent, the right-wing populist New Democracy party won Parliamentary representation. Anti-immigration was a part of their agenda; controversial, sometimes blatantly xenophobic, statements by party representatives contributed to bringing media attention to the issue. New Democracy imploded and was voted out of Parliament in the 1994 election (Rydgren \& van der Meiden, 2019).

However, immigration issues would intermittently become part of political campaigns. Less than two months before the 2002 election, the Liberal Party presented an immigration and integration policy package. Even if the proposals were arguably not designed to primarily reduce immigration, that was how voters interpreted them. In the election, the Liberals almost tripled their vote, and evidence suggests that the immigration package 
was a part of their success (Holmberg \& Oscarsson, 2004; Widfeldt 2015).

Although the SD has doubled their vote share in every election since 1998, the mainstream Swedish parties rarely politicized immigration. Once the SD had won representation in Parliament, however, they worked to politicize immigration. Now, a substantial minority of Swedish voters want a tighter immigration and asylum policy and consider this issue more important than most other issues. This continued politicization of immigration can partly explains why the SD has increased its vote share in every election since 2010 (Rydgren \& van der Meiden, 2019).

After the SD won Parliamentary representation, the Alliance lost its majority but continued in government. Up until 2010 , partly for coalition and strategic reasons, the mainstream right-wing parties used a dismissive strategy vis-à-vis the SD. This was successful for a long time, and likely one of the reasons why the SD's electoral breakthrough took so long (Rydgren, 2010; Dahlström \& Esaiasson, 2013). However, as the mainstream parties have converged on immigration issues, it has benefited the SD for at least two reasons: i) Liberalization of immigration policy contributed to the politicization of immigration and put the issue higher on the agenda; and ii) The increased convergence on the issue gave the SD a monopoly over offering a more restrictive immigration policy program (Loxbo, 2014; Rydgren \& van der Meiden, 2019).

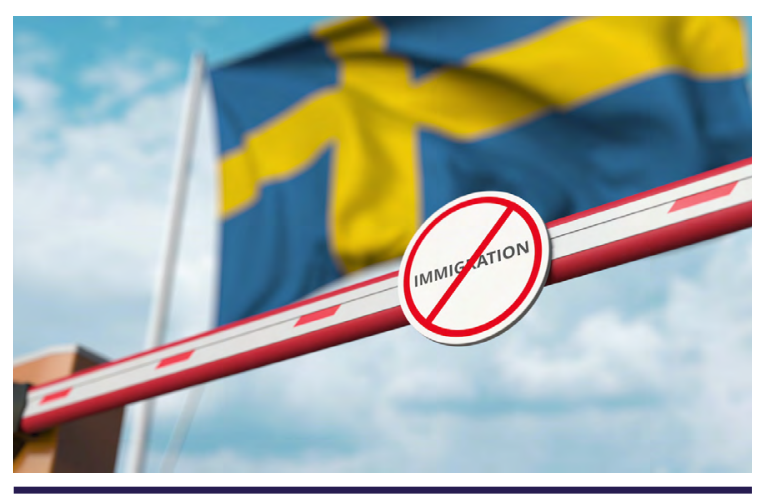

\section{Immigrants:} Approaching Doom, Decay, Enemies, and Threats

As immigration increased, the PRR party positions were linked to communitarian and nationalistic values, defining immigration as a threat to national values and culture. A study (Kriesi et al. 2006, 2008) shows that the potential political tension between the "losers" and the "winners" of globalization have been incorporated into the existing two-dimensional national political spaces. It is this split between socioeconomic winners and losers that has allowed PRR parties to use xenophobia to expand their bases of support. Such a shift allowed the SD to chip away voter from the Social Democrats' traditional core group - the working class (Oskarson, Demker, 2015).

Certain groups have been left behind by globalization. This has resulted in a weak and insecure attachment to the labor market. Many members of these groups will seek out someone to blame. Their resentment might quite plausibly be directed toward asylum seekers or immigrants and, as a consequence, a party arguing for more restrictive immigration policies can become politically attractive (Strömblad \& Malmberg, 2016).

On the other hand, new PRR parties usually give priority to issues related to national identity. More specifically, the new radical right builds on the idea of ethno-pluralism, an idea that largely agrees with right-wing ideas going back 
to Herder (Berlin, 1976; Holmes, 2000) and that in modern times was elaborated by the French Nouvelle Droite. The notion of ethno-pluralism states that in order to preserve the unique national characters of different peoples, they have to be kept separated; mixing different ethnicities only leads to cultural extinction (Griffin 2000; Minkenberg 1997). By employing an ethno-pluralist ideology, PRR parties claim the right of European national cultures to protect their cultural identities. A further theme of this doctrine is that different cultures and ethnicities can never co-exist peacefully. A peaceful society, according to ethno-pluralists, requires an ethnically homogeneous population (Rydgren, 2008).

The PRR parties have framed immigrants as problems in four different ways: i) As a threat to ethno-national identity; ii) As a major cause of criminality and other kinds of social insecurity; iii) As a cause of unemployment; iv) As abusers of the generosity of the welfare state, which results in fewer state subsidies and the like for "natives." Only the first two of these frames can be treated as a manifestation of the ethno-pluralist doctrine, whereas the latter two can be treated as part of a welfare chauvinist doctrine in which immigrants and "natives" are depicted as competing for limited economic resources (Rydgren, 2008). In such a state of conflict, immigrants are portrayed as illegitimate competitors. Immigration is seen as a zero-sum game in which one side always loses what the other side gains. In addressing welfare chauvinist frames, the new PRR parties have used the idea of "national preference": Giving "natives" priority in jobs, housing, health care, and so on - a proposal that can be characterized as "reversed affirmative action" (Zaslove, 2004; Rydgren, 2003).

In the Swedish setting, natives' increased support for radical right-wing populists can be interpreted as an expression of anti-immigrant sentiments. The group position theory would suggest that natives identify with an in-group consisting of native Swedes and consider immigrants part of the out-group. Natives' increased anti-immigrant sentiments would then be a reaction to a perceived threat to their social position (Barmen, 2019). Typically formulated in terms of the likely result of a struggle over limited resources, conflict theory suggests that "in-groups" will regard "out-groups" with suspicion, or even hostility. Hence, immigrants may be regarded as a burden by native Swedes who feel themselves deprived and frustrated. When such people frequently observe immigrants in their own neighborhoods, their resentment may be translated into a willingness to support a xenophobic PRR party such as the SD (Strömblad \& Malmberg, 2016).

The effect of the share of immigrants in a society on xenophobic PRR party support is conditioned by the overall level of unemployment (Arzheimer, 2009; Cochrane \& Nevitte, 2014; Golder, 2003). Immigration does not directly promote xenophobia in settings where unemployment is low. However, immigrants may be scapegoated in times of economic crises and increasing unemployment rates (Strömblad \& Malmberg, 2016).

The PRR parties' ethno-nationalism is generally based on myths about history. Their programs are directed toward strengthening the nation by making it more ethnically homogeneous and by returning to traditional values. Overall, anti-immigration sentiments are the most critical reason as to why voters support the radical right (Rydgren, 2008). The perceived threat against national identity taps into sentiments of nostalgia, the loss of times bygone - of "not feeling at home anymore" - and is translated into ethnic and national terms. This raises the question of how PRR parties construct their ethno-nationalist message. (Elgenius \& Rydgren, 2017).

The SD offers an apocalyptic rhetoric inspired by the reactionary conservatism of the late 1800s and early to mid-1900s; it also offers a rebranded version of the concept folkhemmet along ethnic lines. A Swedish Golden Age is pitted against the decline of the past 50 years. (Dahlqvist 2002; Elgenius \&Rydgren, 2019). Sweden of the 1950 s is portrayed as a safe, cohesive society with a homogeneous population - a symbol of traditional life. This image may attract voters with a conservative ethos. 
Yet, the SD shows some signs of repackaging and rebranding their rhetorical message over time. Approaching doom, decay, enemies, and threats posed by immigration with more caution in the party's official literature has contributed to increasing its voter base. When it comes to the SD's core ethno-nationalist ideology, the party shows considerable continuity, and it has ethnicized Swedish politics by merging the ideals of ethnic-nationalism with Swedish democracy. Such a merger is supposed to help the SD reconstruct a Swedish golden age in the future (Elgenius \& Rydgren, 2017).

In the 1970s, Sweden began accepting growing numbers of immigrants, many of them refugees. Immigrants from countries such as Afghanistan, Chile, Iran, Iraq, Somalia, and Turkey started slowly but surely changing the country's demographics in ways that made some Swedes uncomfortable (Ekman, 2018). Olof Palme, Swedish Prime Minister at the time, was identified as the primary villain and was accused of "rabid internationalization" and "senseless migration policies," allegedly to strengthen the Social Democrats at the ballots. Meanwhile, the "politically correct elite" - socialists and liberals - were blamed for allowing non-European migration from "ethnically distant or remote places." The elite were accused of failing the nation by embracing multicultural values and by promoting membership in the European Union (EU), resulting in the loss of Swedish sovereignty (Elgenius \& Rydgren, 2017).

Since the 70s, there has been a slow but steady increase in the number of asylum seekers, with some notable spikes. The average number of asylum seekers per year in Sweden between 1984 and 2017 was 31,500. During the 1980s, most of the asylum seekers came from the Middle East and the horn of Africa. In the early 1990s, the Yugoslav wars released a wave of refugees, primarily Bosnians. Thus, the inflow of asylum seekers in Sweden rose sharply, peaking above 84,000 in 1992. During the late 1990s, the numbers dropped. They gradually rose again during the 2000 s, reaching approximately 30,000 in 2011. After the onset of the war in Syria, the number of asylum seekers rose sharply and, in 2015, the number of asylum seekers reached almost 163,000 (Barmen, 2019). At that point, many Swedes decided they'd had enough.

As a reaction to the asylum seekers, the Swedish Parliament decided to change the Swedish refugee migration regulations. Sweden went from having the most generous refugee migration regulations in Europe to adopting the minimum level required for an EU member state. As a consequence, the number of asylum seekers fell drastically again during 20162018 (Mottagandeutredningen, 2018). Of the asylum seekers that arrived during the wave of 2015, 78 percent were from Syria, Afghanistan, Iraq, Eritrea, or Somalia. (Mehic, 2019). The SD singled out migration from non-European countries as the cause of moral decay and as especially harmful to Swedish cohesion, claiming it results in "high crime numbers, divorces and broken homes, abortions and low Swedish nativity." The rhetoric of decay includes the destruction of a distinct Swedish culture, common cultural roots, collective memories, and cultural homogeneity. Thus, non-European immigrants threaten Swedish interests. This is contrasted with the SD's version of the "inherited essence" of Swedish identity and culture - one of a mixed Western and European heritage.

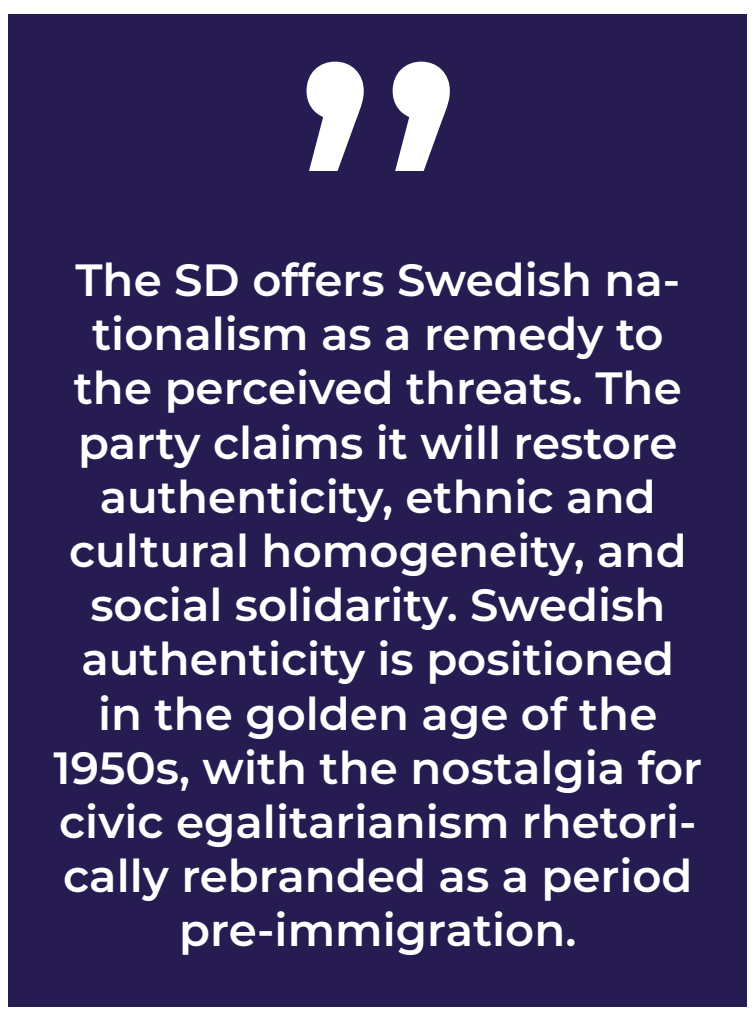


This "heritage" is propagated with the sole purpose of raising boundaries against non-European and Muslim countries (Elgenius \& Rydgren, 2017).

Kent Ekeroth, Member of Parliament, took the SD's arguments further at a demonstration against refugees in 2015, saying that immigration has been the "destruction" of Sweden and declaring the audience "members of a resistance movement" and "a spearhead... to take our country back" (Expo, 2015). The SD offers Swedish nationalism as a remedy to the perceived threats. The party claims it will restore authenticity, ethnic and cultural homogeneity, and social solidarity. Swedish authenticity is positioned in the golden age of the 1950s, with the nostalgia for civic egalitarianism rhetorically rebranded as a period pre-immigration (Elgenius \& Rydgren, 2017).

Despite the party's rhetoric, its popularity has risen amongst Swedes with non-native backgrounds and was officially at 8 percent in May 2015 (Statistics Sweden, 2015). Intriguingly, more than a tenth of respondents who had grown up outside Europe, or whose parents had, also voted for the SD in the 2018 elections (Aylott \& Bolin, 2019). Since 2014 the SD has substantially increased its support among both foreign-born and foreign-background voters, becoming the third largest party in Sweden among this demographic by 2017 (Wernersson, 2017). According to Aftonbladet, 14 percent of SD members are of immigrant origin (Sköld, 2010). Therefore, it is almost normal to see the SD leader Jimmie Åkesson accompanied by two other SD members - one, a man of Sri Lankan descent, and another a woman with a South Korean background - strongly denounce racism in a campaign film ahead of the 2014 elections (Pettersson et al, 2016).

Meanwhile, SD politicians from immigrant backgrounds often use their personal history to deny the existence of structural racism in Swedish society. They also claim that other parties deny the legitimacy of their SD membership. These claims serve the function of efficiently reversing the racist label and attaching it to the SD's political opponents. Perhaps even more importantly, these members maintain the SD's anti-immigrant political agenda while serving as "proof" of the party having rid itself of its racist past. Thus, politicians with an immigrant or other minority background may become powerful political weapons of an anti-immigration PRR party (Pettersson et al, 2016). 


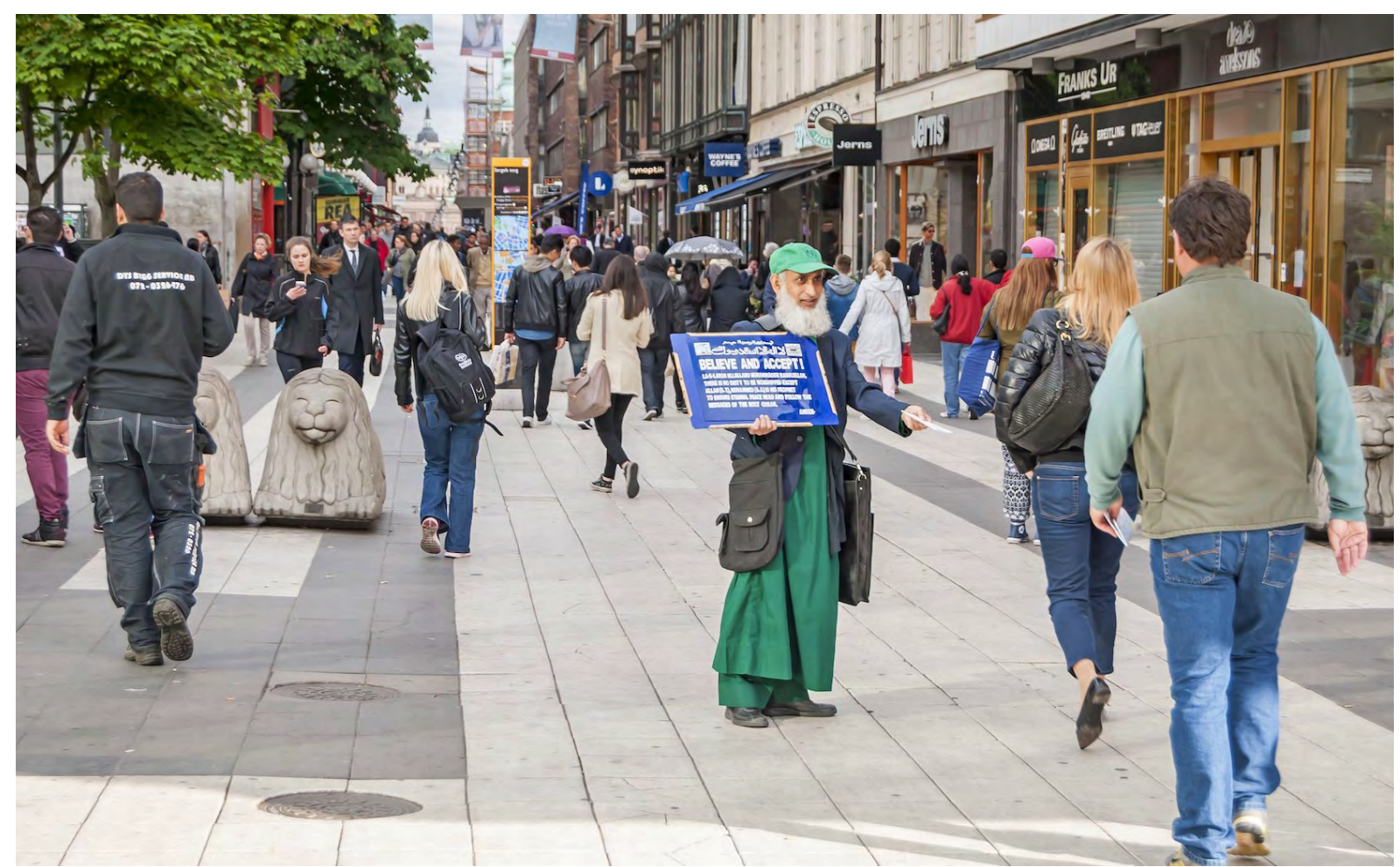

Muslim preacher raising funds in the Drottninggatan (Queen's) street in Stockholm.

\section{Muslims As A "Uni- versal Out-group," Islam As An "Open Threat"}

Sweden has experienced a record influx of asylum seekers fleeing conflicts such as Syria and other predominantly Muslim countries. This wave of Muslim migrants has raised concerns about the current and future number of Muslims in Sweden. In 2016, it was estimated that there are 810,000 Muslims in Sweden, or 8.1 percent of the total population. According to Pew estimations, the number of Muslims in Sweden in 2050 is going to be 1,130,000 (11.1 percent of the population) under a zero-migration scenario; 2,470,000 (20.5 percent of the population) under a medium-migration scenario; or 4,450,000 (30.6 percent of the population) under a high-migration scenario (Pew Research Center, 2017). A report from the Swedish Agency for Support to Faith Communities in 2017 showed that 170,915 of all Muslims in Sweden practice their religion regularly (Statistik, 2017).
On the other hand, since Muslim representation in Sweden encompasses a large variety of ethnic, sectarian, and political outlooks as well as a wide range of language variations, it is impossible to speak of the Swedish Muslim community in static, homogeneous terms. Islam in Sweden is represented by a highly diverse population, which includes Turks, Palestinians, Syrians, Kurds, Moroccans, Iranians, Iraqis, Pakistanis, Bosnians, Kosovars, Somalis, and Afghans, as well as a number of Swedish converts (Berglund, 2015).

Muslim immigration to Sweden began in earnest in the 1950s and 1960s with labor migration and continued into the 1980 s with the establishment of a liberal refugee policy. Although the refugee policy has somewhat tightened since the eighties, Sweden accepted a larger proportion of refugees than any other country in the EU in 2013. (Remember that in the 2014 election, the SD received nearly 13 percent of the vote, making it the third largest party in the country (Berglund, 2015)).

As in most European countries, Muslim immigrants in Sweden have also emerged as the "universal out-group" - meaning, the most culturally distant group that is 
often the focus of debates on issues of immigration and integration (Müller et al, 2016). On this fertile anti-Islam ground, the SD's leader Åkesson has argued that the minaret, a tangible symbol for the "new" multicultural Sweden, generates a feeling of insecurity among the Swedish people (Hellström \& Nilsson, 2010). A 2018 poll by Sifo also showed that 60 percent of the 1000 participants wanted to ban the Islamic call to prayer from loudspeakers in the country, while 21 percent responded this should be allowed; 19 percent were undecided (Göteborgs-Posten, 2018).

According to Brubaker, there is a "partial shift from nationalism to "civilizationism'" in the Western world, and this shift is driven by "a striking convergence in the last 15 years around the notion of a civilizational threat from Islam" (Brubaker, 2017). This shift has promoted the rise of an identarian Christianity.

\section{9}

In its early years, the SD party programs described immigration in terms of "suicide politics": this meant policies that promoted migration, internationalization, and the "Islamification" of Sweden. The party spent the next decade warning about the "dying nation," its "terrible plight," and the "dark future ahead."

Civilizationism has come to constitute an increasingly important part of the rhetorical nexus of exclusion and competition within ethno-nationalism. More generally, the resonance of anti-Muslim messages became more pointed after September 11, 2001 , and in connection to recurrent Islamist terror attacks (Kallis, 2018). In many countries, after September 11, criticizing Islam abroad and at home became a social- ly acceptable alternative to more openly xenophobic statements (Arzheimer, 2018).

Under these circumstances PRR parties and movements have found opportunities to mobilize people on the basis of both national and religious identities, defending what they call the Judeo-Christian identity against the threat of Islam (Minkenberg, 2018). In the case of the SD, the rhetoric and discourse of Swedish homogeneity, culture, and identity highlights the considerable complexity and contradictions of the ethno-nationalist argument: Swedish homogeneity is simultaneously proposed to be an integral part of the European, Western, and Christian cultural communities. (Elgenius, Rydgren, 2019).

In its early years, the SD party programs described immigration in terms of "suicide politics": this meant policies that promoted migration, internationalization, and the "Islamification" of Sweden. The party spent the next decade warning about the "dying nation," its "terrible plight," and the "dark future ahead" (SD Kuriren, 1996; 2001; 2003). Since the SD worldview assumes and warns about clashes between peoples with different cultural values and with peoples of "remote cultures," these conflicts are avoided by these groups living separately. Such cultural segregation constitutes a basis of the SD's prognostic frame. Thus, the SD introduced its approach to Swedish identity and nationality as an open form of Swedishness (Elgenius, Rydgren, 2019).

A vignette study conducted shortly before and after the 2014 national election helps to analyze the social distance between the majority population and the Muslim minority in Sweden. Study's results showed that: i) Anti-minority attitudes, held by 36 percent of the population, predict increased social distance from Muslims and even towards persons that having a foreign-sounding name; ii) $S D$ voters hold drastically more negative views than any voting bloc about Muslims; iii) A vote for the SD was purely driven by anti-minority - and not anti-establishment - sentiments. Namely, while the SD might present its cause in the language of anti-establishment populism, and their voters might legitimize their voting choice 
by this principle, SD voters' intentions have been fundamentally rooted in xenophobia, specifically anti-Islam xenophobia. In the same study, around 35 percent of respondents agreed somewhat or strongly with the view that minorities' rights are given too much weight at the expense of the general population. SD voters were more likely than supporters of other parties to agree with this sentiment; and they were less likely to accept a Muslim as a neighbor, caretaker, or family member (Müller et al, 2016).

Muslims were the least accepted bloc in the country, across all dimensions; according to Müller et al (2016) this could be due to negative attributes that are part of stereotypes but unrelated to the cultural content ascribed to that stereotype. For instance, respondents might have held more negative attitudes towards Muslims because Muslims are perceived as "foreign" or more religious (religiosity being viewed with suspicion), or as having a lower socio-economic status (indicated by a lower education level). The only characteristic that mattered in the evaluation across the general population was the description of a person as "Muslim." Meanwhile, Muslims that were described as volunteering for a secular cause were perceived as more favorable than those volunteering for a mosque. However, Christians that volunteered for a church did not suffer from more negative evaluations (Müller et al, 2016).

The social distance toward Muslims among SD voters was higher in 2010 when compared to 2014, which would support the hypothesis of an increased variation within their electorate in the recent elections. But for respondents who voted for the SD in 2014 , only 40 percent were willing to accept a Muslim as their neighbor; 50 percent would approve if a Muslim cared for their elderly parents; and only 20 percent would accept a Muslim who married into their family. Among the other voter groups, around 85 percent would accept a Muslim as neighbor or nurse, while 60 percent would accept having the person as a family member. The results confirm that SD voters hold drastically more negative views towards Muslims than voters of other Swedish parties (Müller et al, 2016).
The study indicated that the choice to vote for the SD is driven by anti-minority, specifically anti-Muslim, sentiments; and that SD voters are ideologically motivated (as opposed to being protest voters) (Müller et al, 2016). SD voters also agreed with the sentiment that migrants in general, and Muslims in particular, were a burden to the Swedish welfare state, because "they do not work, they cheat and misuse the resources of the welfare state." They agreed strongly with the idea that Muslim migrants were a threat to the Swedish nation, due to their perceived background in patriarchal cultures and religions, and to their resistance to assimilation (Mulinari et al, 2014). Swedish media has often depicted Islam in a negative light, with Muslim immigrants regularly portrayed as being backward and resistant to democracy, secularization, and the separation of religion and state (Berglund, 2015).

According to another survey conducted in 2006-2007, fundamentalist newspaper Världen idag and the SD's official newspaper SD-Kuriren tended to describe Muslims and Islam as threatening, and "our" elite as retreating. In these two media outlets, Muslims were consistently described as aggressive and the cause of social and political problems. In both, Muslims were correlated to negative behavior; good Muslim behavior was constantly disregarded, while bad behavior was assumed to reflect their true character. Världen idag also claimed that Islam is incompatible with democracy. Meanwhile, liberal Dagens Nyheter and Evangelical Dagen avoided describing Muslims and Islam as a threat and more often sought constructive solutions to different problems. Moreover, Dagens Nyheter described conflicts between Muslim and Christian actors in political, not religious, terms (Steiner, 2014).

Actors in the anti-Muslim landscape have an especially strong online presence, with their own digital news media, blogs, podcasts, Facebook groups, YouTube channels, and keyboard warriors (Gardell \& Muftee, 2018). Among social media users, the SD dominates among all parties in parliament, engaging 29 percent of Facebook users and 42 percent of Twitters (Hagberg, 2017). By constantly recycling certain themes (e.g. that Mus- 
lims are inherently violent, constitute a demographic threat, and infiltrate society by strategies of stealth jihad and creeping sharia) they have pushed the limits of what is considered acceptable public speech about Muslims in an effort to facilitate more space for anti-Muslim political actors, decision- and policymaking (Ekman, 2015).

A 2017 study Det vita hatet (The White Hate) analyzed prominent Swedish "hate sites" Nordfront, Avpixlat, Motgift, Nordisk ungdom, Nya tider, and Nyheter idag with a special focus on the two largest forums, Avpixlat (today Samhällsnytt, and with links to the SD) and Nordfront (associated with the Nordic Resistance Movement). A recurring theme was the narrative about Swedish female victimization to alien Muslim male offenders (Kaati, et al. 2017).

\section{Islamophobia Works Better Without Muslims}

Furthermore, a varied body of research indicates that Islamophobia and hate crimes are on the rise in Swedish society. Reports of hate crimes based on Islamophobia grew from 278 in 2011 to 439 in 2016. Discrimination based on religion and ethnicity remains a significant social problem in labor recruitment (Skodo, 2018). Some other studies, however, show that over the years, there has been a decrease in the number of Swedes who believe that the country contains "too many foreigners," as well as a steady show of support for the free expression of religion. In a study concerning non-Muslim views on Muslims and Islam, it was found that when non-Muslim Swedes come to know their Muslim neighbors, many of their apparent prejudices and misgivings diminish (Berglund, 2015).

Islamophobic propaganda works best in rural or small-town areas with no or few Muslim residents. This is congruent with the fact that the anti-Muslim SD draws most of its support from voting districts with no or few Muslim residents. Islamophobia works better without Muslims
(Gardell \& Muftee, 2018). Another study by a Swedish public agency (Integrationsverket) showed in 2007 that 55 percent of respondents expressed reservations about moving to districts where many Muslims lived (Integrationsbarometer, 2007).

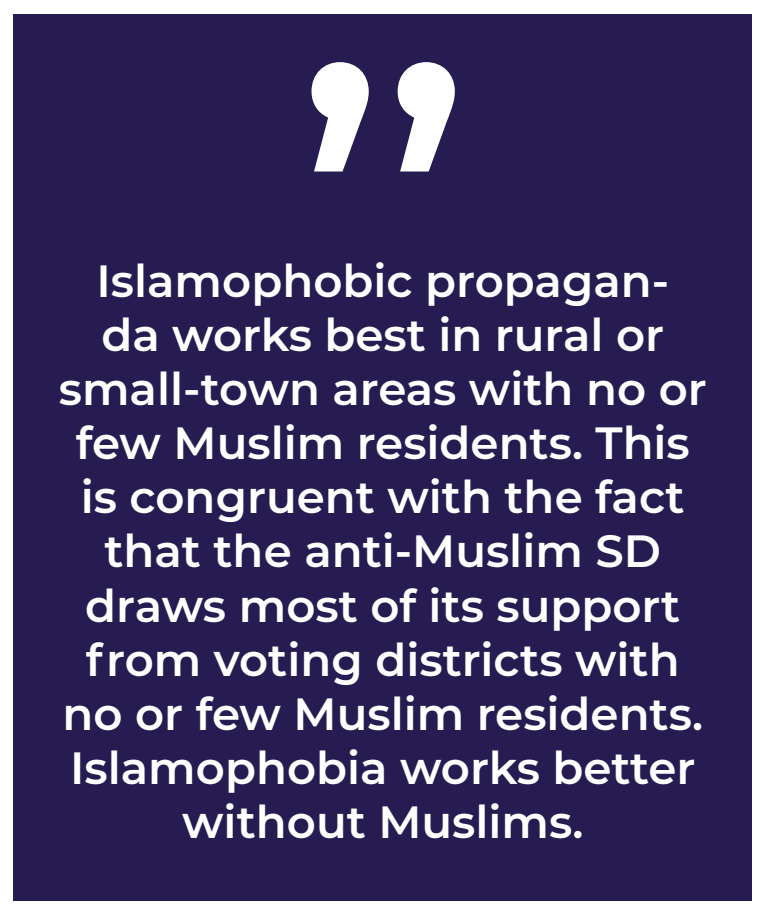

By employing an ethno-pluralist ideology, the PRR parties claimed the right of European national cultures to protect their cultural identities. Parties like the SD claim that there are several "threats" to their national identity, of which the alleged "invasion" of immigrants is the most important; immigrants from the Muslim countries are singled out as particularly threatening to European values. (Zaslove, 2004; Rydgren, 2008). Most Swedes - and most media and political parties - have accepted this demographic and the resulting societal shifts, despite a significant Muslim minority only developing in recent decades. The SD has been the most important exception, and stands as proof that Sweden is still divided; there is a chasm between those accepting change and those 
who do not (Steiner, 2014).

In 2005, the Danish daily newspaper Jyllands-Posten published twelve cartoons allegedly depicting the Prophet Muhammad. They did so under the guise of freedom of speech. The SD gave the paper their unreserved support, stating that it saw no reason why a Danish newspaper should be forced to abide by Muslim rules and prohibitions regarding expression. When a boycott of Danish products was launched in the Middle East, the SD launched a "Buy Danish" campaign (Sverigedemokraterna.se). The SD also directly took part in the cartoon debate in 2006, publishing a cartoon depicting Prophet Muhammad on its youth league (SDU) and SD-Kuriren websites (Holender \& Svahn, 2006).

The publication attracted the attention of the Swedish government, which informed internet service provider Levonline about the SD's publications; Levonline shut down the SD's webpage. The Minister for Foreign Affairs Laila Freivalds condemned the publication as a provocation (Hamrud, 2006; Kihlström, 2006), though she denied any direct interference in the case. However, Freivalds had to resign after being accused of dishonesty and interference with press freedom (Sveriges Radio, 2006).

Meanwhile, the SD also had a hate speech charge filed against it due to the caricature (Janhunen, 2006). Similar hate speech charges were also filed against other Swedish publishers who had depicted Prophet Muhammad. But these charges were immediately deemed to be unfounded by the Swedish Chancellor of Justice (Justitiekanslern) (Svenska Dagbladet, 2006). The SD also planned originally to publish a set of cartoons in SD-Kuriren. After the controversy erupted, party leader Åkesson issued a statement on the SD's website, on February 9, 2006, stating that they would refrain from further publications, due to concerns that publishing might spur hostile actions against Swedes and Swedish interests (SD Kuriren, 2006 \& Sydsvenskan, 2006).

In a strange twist, the SD has historically criticized what it calls a "Homosexual Lobby"; SD-Kuriren regularly published articles attacking LGBT events and describing homosexuality as "perversion" (SD-Kuriren. 2007a \& SD-Kuriren, 2007b), and Åkesson expressed concern that what he describes as the Islamization of Sweden will eventually lead to the rights of sexual minorities being violated (Brandel, 2010). Yet, SD member and former party magazine editor Jan Sjunnesson organized gay pride parades in the Stockholm suburbs of Tensta and Husby, two areas with large Muslim populations. The event was disavowed by the official Stockholm Pride organization and the Swedish Federation for LGBT Rights; in a joint statement both organizations called Sjunnesson "a person who's spreading hatred towards Muslims on social media and who's not supporting LGBT rights" (Naib, 2015 \& Montelius, 2017). The event showed the convoluted logic of the SD's various forms of bigotry. 
During his post-2010 speeches at Almadalen, SD leader Jimmy Åkesson has attempted to enforce the idea that the Swedish native majority constitutes a homogeneous community of blood. Åkesson operated a discursive distinction between those migrant "others" that assimilated into Swedish society and embraced the "Swedish values" underpinning the "Christian, democratic world" that Sweden is part of and those migrant others who failed to integrate and instead had willingly joined "the world's Islamists" (Norocel, 2017). In other words, "becoming Swedish," according to the SD, is not a mere matter of fulfilling the administrative citizenship requirements; rather, it entails a more profound process, which hinges on "cultural commensurability with respect to the foundational values that define Europe's cultural heritage" (Betz \& Meret, 2009).

While acknowledging the difference between Muslim faith and Islamist ideology, Åkesson underlined Christianity and its moral values as central cornerstones of the folkhem. This may indicate a thinly veiled assumption that Muslim faith by itself - described by Åkesson as a deeply patriarchal religion of "genital mutilation of completely healthy children" and of "violence and oppression in the name of honor" - constitutes a hindrance for the migrant Muslim other in their efforts to become a full-fledged and law-abiding citizen of the folkhem, which "had been built on democracy and a thousand-year-old Christian foundation" (Norocel, 2017). 


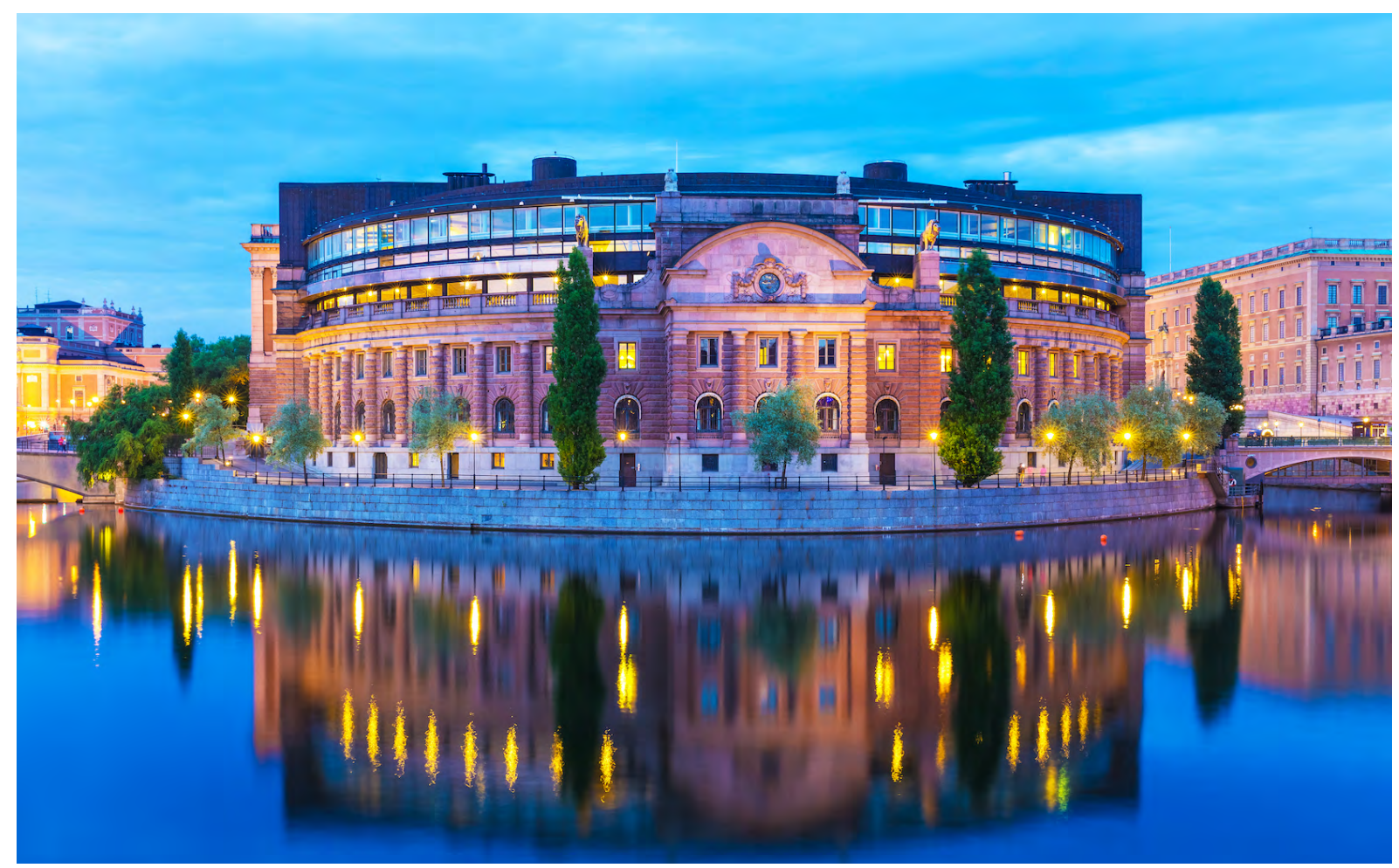

Scenic summer evening view of the Parliament House (Riksdaghuset) in Stockholm, Sweden.

\section{Cordon Sanitaire: Containment of the $\mathrm{SD}$}

Despite earning 17.5 percent of the votes in the 2018 general election and securing 62 seats in Parliament (becoming the third largest party), the SD has been remained isolated in the Riksdag because the other parties have staunchly maintained a policy of refusing to cooperate with it (Radio Sweden, 2014). As the main reason for their distance, they have cited the party's strong preferences for a very restrictive refugee migration policy (Nationalencyklopedin, 2019). A political cordon sanitaire was spontaneously constructed around the party, beginning with its breakthrough results in the 2010 election (Bolin \& Aylott, 2019).

According to the mainstream parties and most of the public, the SD represents a "devil in disguise." Despite the SD employing a strategy of moderation, the political establishment rebuts its claims to democratic legitimacy and claims that the SD cannot be trusted to act in accordance with formal democratic procedures. Other actors bring the SD's deplorable past to the fore, exposing its Nazi leanings and criminal records. The political establishment claims that though the SD has constructed a democratic façade, beneath the surface it remains undemocratic, racist, and violent. Political representatives from the established parties have sought to reveal the party's diffuse past and show constituents the "true nature" of its ideology; the SD is thus guilty-by-association (Hellström \& Nilsson, 2010).

With this rhetoric, mainstream parties seek to justify their means of counteraction, promoting the view that the SD cannot be accommodated in an open and democratic society. Since it is racist, and probably an enemy of democracy, it does not deserve the same respect as other parties. Unfortunately, this strategy of shaming the SD has become counterproductive and reinforced the perception of politics as a matter for elites. The SD exploits its marginalized position to sustain a perception of Swedish politics as divided between a consensual political elite alienated from the people and the SD as a party that safeguards the interests of ordinary people. Thus, the SD aspires to act as "the true heir of a long tradition of protecting people" (Hellström \& Nilsson, 2010). 
Indeed, media interest in the SD and its politics has grown significantly since the 2006 general election. Prior to the election, the SD was not invited to take part in public debates, nor did it run much of a campaign. This followed a long period of describing the SD as an immature and aggressive organization with neo-Nazi tinges (Larsson \& Ekman, 2001). As a result of its success in the 2006 vote, there was reason now pay closer attention to SD as a potential force in Swedish politics. However, the party continued to experience fierce criticism from all the established parties (Hellström \& Nilsson, 2010).

The perception that the SD represents an anomaly in an otherwise consensual political milieu in Sweden is, in a wider European perspective, already outdated (Mudde, 2007). Peter Mair (2002) points out that the political identities of the mainstream parties have become increasingly blurred. This invites new political actors to occupy an underdog position in relation to the established elites (Mouffe, 2005).

In his 2007 speech at the SD annual meeting, Åkesson talked about his experience of being denied access to channels of political information and the problems this caused in his constituency. He claimed that the other parties sought to ridicule the SD, neglecting the fact that SD representatives faced daily discrimination in their political work. He also talked about SD meetings obstructed by violent protests, during which several party members were injured. In his speech, Åkesson concluded that "we are the underdogs," underlining the frequently adopted rhetorical figure: "We are the democratic victims" (Åkesson, 2007).

According to SD pundits, in the process of transforming the party along more moderate lines, the SD has committed to democratic norms; however, none of the other parties have worked with them. Thus, SD representatives have been able to nurture their position as democratic underdogs (Hellström \& Nilsson, 2010). They have portrayed themselves as friends of the people and, at the same time, sharp critics of a consensual elite that refuses to engage in dialogue and deliberation with the SD. On the party's website, a list of "objective" criteria is presented to help the reader assess the political actors according to democratic standards. In this regard, the SD's message is underpinned by another rhetorical flourish: "We are the true democrats" (Rydgren, 2002). Its view is that the established parties promote neither dialogue nor freedom of speech. The SD further argues that the democratic system has become increasingly bureaucratized, making it an affair for the political elite. The SD vision is that the people should enjoy strong direct political involvement as a complement to existing representative politics (Taggart, 2000). The strategy of ostracizing the SD not only allows the party to play the victim, but also risks belittling SD voters, triggering feelings of frustration among the electorate and sustaining an elitist perception of Swedish politics (Hellström \& Nilsson, 2010).

To understand the processes in which radical right-wing parties gain increased legitimacy, one needs to consider mass media (Andersson, 2010 \& Ellinas, 2010). Media coverage is important not only because it contributes to the visibility of the party, which is crucial for new parties lacking economic resources, but also because it may contribute to increased legitimacy and respectability as well as name recognition (Ellinas 2010). In the run-up to the 2010 election, for example, the SD received more media publicity than some established parties, such as the Christian Democrats and the Left party. This was immensely important for a small party lacking economic resources, even though much of the coverage was negative.

Seemingly, PRR parties are less sensitive to negative publicity, compared to mainstream parties (Ellinas, 2010). One potential explanation is that the mass media are seen as a part of "the political establishment," which is believed to be conspiring against the populist radical right (Andersson, 2010). The SD has also complained about difficulties buying advertising space due to the media banning the party from advertisement (BHHR, 2002). On June 16, 2006, the papers Dagens Nyheter and Svenska Dagbladet decided to end their boycott. 14 years later, Expressen still retains a ban on SD advertising (Letmark, 2006). 
This has contributed to a widespread distrust of the media among SD supporters. Among them, for example, 93 percent believe that Swedish media does not tell the truth about immigration (Demker, 2015). In addition, over the past decade, alternative, online-based news media have become increasingly important, and the SD has been successful in, directly or indirectly, launching such media advocating for its political program (Krzyzanowski et al. 2016; Rydgren \& van der Meiden, 2019).

Gaining political legitimacy has allowed the party to sidestep some of the media's reluctance to cover it. Almedalen week is a gathering of political parties, lobby groups and businesses, public administration representatives, and journalists on the island of Gotland. All political parties represented in the Swedish Parliament are also granted their own "party day" at this "political spectacle" (Wendt, 2012); the high point of this one-day political action is represented by the party's chairperson delivering their speech (Norocel, 2017). Since the SD passed the Parliamentary threshold in the 2010 election, it has been included in Almedalen week. Consequently, Åkesson has delivered speeches summing up "the SD day," effectively bypassing the cordon sanitaire that the Swedish media had previously attempted to maintain around the SD and its leader (Loxbo, 2015).

Still, the media and rival political parties have maintained their strategy of ostracizing the SD whenever possible. The success of this strategy is debatable: the SD has increased its vote share in both the 2014 and 2018 elections. Shifts in political alignment have also benefitted the SD. The left has been damaged by the dissolution of the traditional class-based, left-right divide. This has been replaced by what is known as the GAL-TAN divide: GreenAlternative-Liberal versus Tradition-Authoritarian-Nationalist. This is a new political landscape in which traditional economic issues, to a large extent, are replaced by lifestyle and identity issues. From a sociological perspective, most of the people who used to vote for the Social Democrats - blue-collar workers and the lower middle class - now vote for the SD (Rothstein, 2014).

Despite the SD's electoral success - and

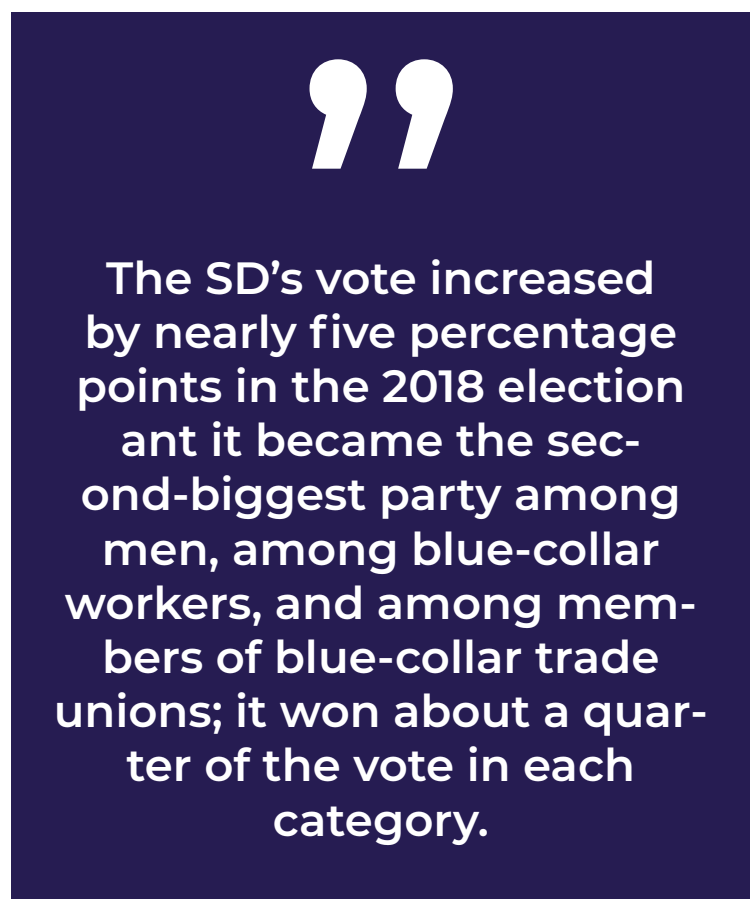

despite the center-right prime minister acknowledging in 2014 that immigration had become an expensive policy choice for Sweden - no mainstream party has defected from the policy of cordon sanitaire with regards to the SD. This left the SD as the only party voicing any skepticism about immigration (Backlund, 2016). Only in late 2015, a year in which 163,000 asylum-seekers poured into Sweden, did mainstream parties finally agree to tighten immigration policy. However, because the cordon sanitaire endured in the parliamentary arena, stable majorities that included the SD were ruled out, too. Indeed, after the 2014 election, mainstream parties formed a formal cartel designed to maintain the SD's isolation (Bjereld et al, 2016).

There followed weeks of sparring between the new government and the Alliance, ostensibly over the budget but more essentially over how they were to handle the disruptive presence of the SD (Aylott \& Bolin, 2019). Stefan Löfven, the prime minister, dramatically called a new election. Equally dramatically, he then called it off. His Social Democrats, the Greens, and the Alliance parties instead reached the 2014 "December agreement" (Bjereld et al, 2016). The agreement was made possible by an extraordinary innovation: Each of the two blocs agreed to allow the bigger one to form a government and get its budget through parliament (Aylott 
\& Bolin, 2019). The aim was clear: to construct a cartel that would exclude the SD from all influence. It was almost as if the parliamentary arena was to be truncated, with seven parties acting as if the eighth was not there (Kinberg Batra et al, 2014). The party system was fundamentally changed. Far from a two-party system, competition now resembled "polarized pluralism" (Sartori, 2005).

For decades, it was received wisdom that Swedish elections were fought over economic distribution. In 2014-2018 such issues became augmented, and even supplanted, by others: immigration, the social integration of newcomers and, not least, law and order. The media began to associate rises in levels of violence and crime with migration. Tension rose further after an Islamist terror attack in Stockholm in April 2017, in which five people died. Under these circumstances, the Moderates sought to pull the Alliance towards a quite different strategy, in which the cordon sanitaire around the SD would be relaxed. This was enormously controversial; for many in the other Alliance parties, any accommodation with the SD was unthinkable (Aylott \& Bolin, 2019).

The SD's vote increased by nearly five percentage points in the 2018 election. In an election in which, according to the exit poll, two in five voters switched their preference from the previous election, the $\mathrm{SD}$ retained nine in ten of its voters from 2014. In 2018, the SD became the second-biggest party among men, among blue-collar workers, and among members of blue-collar trade unions; it won about a quarter of the vote in each category. There was speculation, too, that the party's growth could also have contributed to another striking result: that turnout rose for the fourth consecutive election, to over 87 percent. The SD might have mobilized voters who would otherwise have abstained (Aylott \& Bolin, 2019).

The 2018 election induced profound change in the Swedish party system. The fragmented format became more evident (Bolin, 2018). Above all, the bloc-based, bipolar competition that had (with periodic exceptions) characterized politics since the 1970s, and which reached a peak of formalization in 2010, disappeared as the
Alliance collapsed. The Center refused to compromise on the founding motivation for the 2014 December agreement: ostracism of the SD. The new government meant that the Center and the Liberals had maintained the cordon sanitaire, but the diverse Parliamentary majority has little to unite it beyond antipathy to the SD (Aylott \& Bolin, 2019).

A majority of Swedes share the mainstream parties' disdain for the SD. According to a 2016 survey, more than half - approximately 51 percent - of the respondents said that they prefer the SD least among all parties. Even with the SD's evolution, there remains a large resistance to the party. The survey also suggested that only two parties could eventually form a coalition with the SD: Moderates (M) and the Christian Democrats (KD). The majority of these parties' supporters did not identify rate the SD lowest in preference (Eger \& Hjerm, 2018).

As predicted, the cordon sanitaire was breaking down by spring 2019 (Bolin \& Aylott, 2019). First, the SD was blurring some of its economic positions, partly to facilitate cooperation with established parties; and later Åkesson, began to talk hopefully of a new "conservative bloc" comprising the SD, the Moderates, and the Christian Democrats (Bolin \& Aylott, 2019). As he expected, Christian Democratic leader Ebba Busch Thor announced in March 2019 that her party was ready to start negotiations with the SD (Hamidi-Nia, 2019). In December 2019, Moderate Party leader UIf Kristersson also held an official meeting with the SD leadership for the first time. This led to speculation that the SD could be included in a new center-right group to replace the Alliance, which had collapsed after the Center Party and the Liberal Party chose to support the Social Democratic-led government (Financial Times, 2019). 


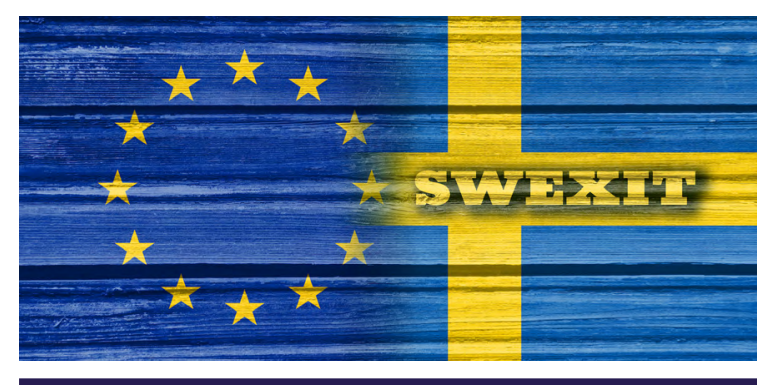

The SD Follow the Line of Other PRR

\section{Parties:}

\section{Euroscepticism}

When the three Nordic states - Finland, Norway, and Sweden - applied for EU membership in the early 1990s, several commentators expected that they would pursue rather similar integration policies. However, as Norwegians rejected membership two times, Swedish EU policy could be described as cautious and hesitant, with the Swedes rejecting the single currency in a referendum in 2003. Only Finland has acted, contrary to the expectations, consistently in favour of deeper integration (Raunio, 2007). In contrast, even the referendum on EU membership in Sweden was highly divisive, with a very narrow majority in favour of joining the Union. Moreover, all parties are divided over further integration (Bolin \& Aylott, 2019).

Eurosceptic strategies are quite attractive to PRR parties because they present an effective method for carving out political space. In national elections, the $\mathrm{EU}$ issue is often seen as a comparatively cost-free strategy for populist parties to articulate their opposition to the political mainstream. Therefore, Euroscepticism plays an important role in the explanation of the variable fortunes of PRR parties in the Nordic countries (Ketola, \& Nordensvärd, 2012). Complying with the line of other PRR parties, the SD has been a fierce critic of the EU since the party was founded, and it has always been against further integration. The party also rejects joining the Economic and Monetary Union (EMU), aims to renegotiate Swedish membership in the Schengen Agreement,

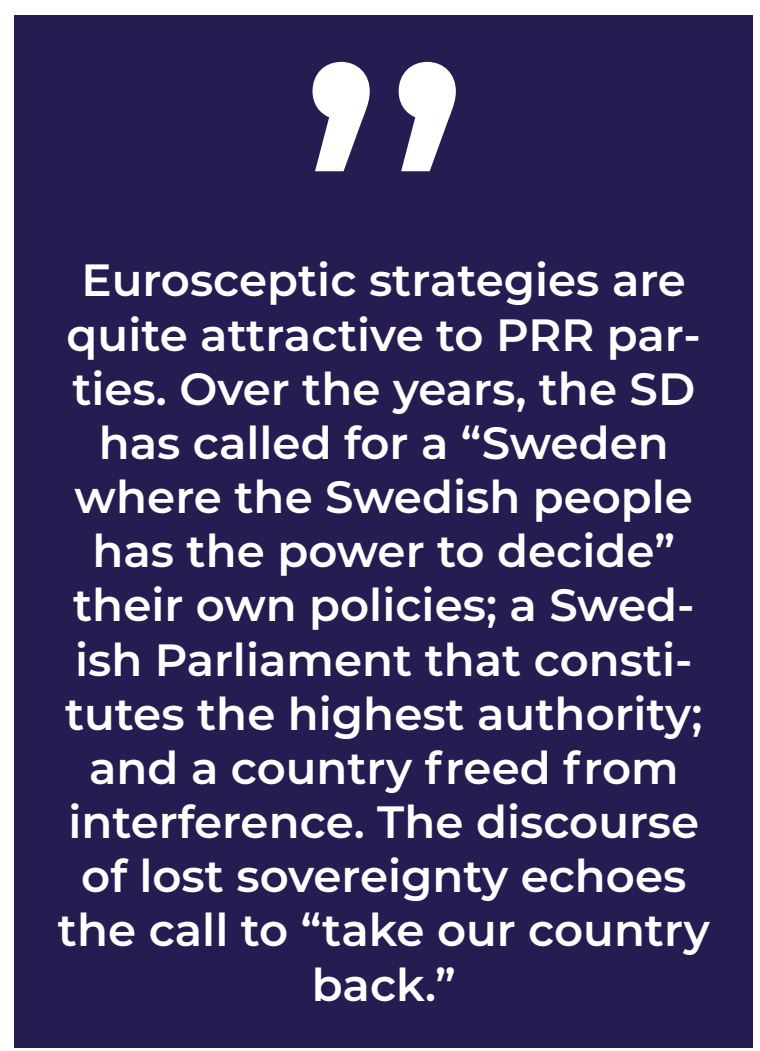

reduce Swedish financial contributions to Brussels, and is opposed to creating a combined European defense budget (Radosevich, 2018).

It is obvious that, like many other PRR parties, the SD favors a Europe of sovereign nations (Widfeldt, 2000). They argue that the EU should be based on more of a co-operative model rather than on a federal state. The SD wants to re-negotiate the EU treatment, but there are no official demands to leave the Union. The party has rather explored the political opportunity of nationalism where it focuses on Sweden's national identity (Rydgren, 2003). Since the SD put a focus on the nation state (Ketola, \& Nordensvärd, 2012), the party's action program states that, "Sweden should be a sovereign and an independent state. ... abolishing a nation state and jeopardizing the survival of a culture is too awful" (Hellström \& Nilsson, 2010).

Moreover, the SD blames the Social Democrats and the Liberals for undermining Swedish solidarity and cohesion through the internationalization and multicultural values that they promote. Along similar lines, the "politically correct elite" is accused of failing Sweden by embracing membership in the $\mathrm{EU}$, resulting in a loss 
of Swedish sovereignty and "the national independence and freedom we held for centuries." Over the years, the SD has called for a "Sweden where the Swedish people ha[ve] the power to decide" their own policies; a Swedish Parliament that constitutes the highest authority; and a country freed from interference (Elgenius, Rydgren, 2019). The discourse of lost sovereignty echoes the call to "take our country back" (Bhambra 2017).

Most attempts to uncover links between parties like the SD and more radical actors in Europe search for ideological common denominators. Undoubtedly, the most famous theory comes from historian Roger Griffin, who claims that many anti-immigrant forces in Europe share a fascist ideology (Teitelbaum, 2018). However, following the European election of 2014, the SD elected not to join other far-right movements and instead became a member of the more moderate right-wing Europe of Freedom and Direct Democracy group, along with the UK Independence Party (UKIP).

In 2015, the SD began forging closer relations with the neighbouring Danish People's Party and in 2018 announced an official cooperation pact with the Finns Party (The Local, 2015 \& Yle, 2018). In 2018, the SD joined both the European Conservatives and Reformists group in the European Parliament and the European Conservatives and Reformists Party in which it sits alongside the British Conservative Party. Åkesson said concerns over Russia would make it very hard for the SD to cooperate with some other right-wing parties "that are more or less Putin friendly" (Ahlander, 2019).

A poll by Statistics Sweden (SCB) published in June 2019 showed that Swedes prefer the status quo in the present relationship with the EU: Nearly 62 percent supported Swedish EU membership (EIU, 2019). The SD's Euroscepticism, meanwhile, which had previously involved advocacy of a renegotiation of Sweden's EU membership and possible departure, was toned down in light of Britain's troubled exit from the Union (Åkesson, 2019); the "Swexit" agenda lost its momentum. Citing uncertainty over Brexit and the growing resistance to federalism in many other European parties, Åkesson said that the SD now hoped to change the EU from within. "We will not make any demands for leaving the EU or conducting a referendum," Åkesson said in an interview. "We want to be part of the EU internal market. We should cooperate in areas which benefit Sweden, but we need to get away from supra-nationalism." (Ahlander, 2019). 


\section{CONCLUSION}

Like all liberal democracies in the 21st century, Sweden also faces challenges associated with globalization, international migration, and growing inequality. Despite its reputation as a moral superpower, Sweden is not uniquely immune to racism, nationalism, xenophobia, Islamophobia, and anti-immigrant sentiment. Yet the picture is perhaps not so dark: although the SD's message may appeal to 1 in 5 voters, it does not appeal to the vast majority of Swedes. More than 50 percent of the public rate the SD lowest among their party preferences. The SD is unique in this regard. On average, other Swedish parties only receive 4 percent of the "least liked" vote (Eger \& Hjerm, 2018).

Moreover, the Sweden Democrats, in lines with other parties of the populist radical right (PRR) across Europe, have shown some signs of moderation, repackaging and rebranding of their rhetorical message over time. For instance, today the party avoids nostalgia for the 1930s, a notable characteristic of early members in the party's formative years. The party also approaches doom and decay, threats to the nation, enemies within or without, justifications for political action, and solutions to identified problems with more caution in official party literature, which has contributed to increasing its voter base (Elgenius \& Rydgren, 2019).

Yet, by polishing its message, the party has considerably ethnicized Swedish politics through a rhetoric based on ethnic nationalism, Swedish democracy, and a contradictory promotion of the nation as an ethnic democracy (Elgenius and Rydgren 2017). With the ethno-nationalist message in mind, one can argue that there is a considerable continuity regarding the diagnostic frames used by the Sweden Democrats over the past 20 years, even as the party presents itself in less-radical ways (Elgenius \& Rydgren, 2019). 


\section{REFERENCES}

- (1996, 2001, 2003). SD Kuriren, No 27, 1996; No 43, 2001; No 51, 2003.

- (2005). "Partiets historik i kronologisk ordning." Sweden Democrats. https://web.archive. org/web/20101129031803/http:/sverigedemokraterna.se/vart-parti/partiets-historik-i-kronologisk-ordning/ (accessed on June 8, 2020).

- (2006). "Sverigedemokraterna avstår från vidare publicering av Muhammedbilder av hänsyn till svenska liv." SD Kuriren. Feb.9, 2006. https://web.archive.org/ web/20070807130853/ http:/www.sdkuriren.se/nyheter.php?action=fullnews\&id=1368 (accessed on June 7, 2020).

- (2006). "Sverige dras in i Muhammedkonflikt." Sydsvenskan. Feb.9, 2006. https://www. sydsvenskan.se/2006-02-09/sverige-dras-in-i-muhammedkonflikt (accessed on June 7, 2020).

— (2006). "Stöd Danmark—Köp danskt!" Sverigedemokraterna.se. Feb.13, 2006. https:// web.archive.org/web/20060502182151/ http://www.sverigedemokraterna.net/kampanj_ dk.php?action=fullnews\&id=569 (accessed on June 6, 2020).

- (2006). "Media Follow-ups to Freivalds Resignation." Sveriges Radio. March 22, 2006, https://sverigesradio.se/sida/artikel.aspx?programid=2054\&artikel=821337 (accessed on June 7,2020 ).

- (2006). "Kritik mot stängning av nättidning." Svenska Dagbladet. Feb.10, 2006.

https://www.svd.se/kritik-mot-stangning-av-nattidning (accessed on June 7, 2020).

- (2002). "Swedish General Election 2002: media coverage." British Helsinki Human Rights Group (BHHR). https://web.archive.org/web/20070927212926/ http://www.bhhrg.org/CountryReport.asp?ChapterID=239\&CountryID=51\&ReportID=83 (accessed on June 9, 2020).

— (2007). Integrationsbarometer 2007. Norrköping: Integrationsverket. https://web.archive. org/web/20100820064059/ http:/www.temaasyl.se/Documents/IV/Integrationsbarometer\%202007.pdf(accessed on June 5, 2020).

- (2007a) "Homosexlobbyn kräver, och homosexlobbyn får." SD-Kuriren. Aug.3, 2007. https://web.archive.org/web/20071109003023/ http://www.sdkuriren.se/blog/index.php/ soder/2007/08/03/homosexlobbyn_kraver_och_homosexlobbyn_f(accessed on June 7, 2020).

— (2007b). "Kulmen nådd på perversiteterna." SD-Kuriren. Aug.5, 2007. https://web.archive. org/web/20071109003047/ http://www.sdkuriren.se/blog/index.php/soder/2007/08/05/kulmen_nadd_pa_perversiteterna(accessed on June 7, 2020).

- (2010). "Sverigedemokraterna - från gatan till parlamentet." Expo, August 25, 2010. https://expo.se/arkivet/2010/08/sverigedemokraterna-från-gatan-till-parlamentet (accessed June 3, 2020).

- (2014). "Sverigedemokraternas vitbok 1988-2014," Expo, Sept, 12, 2014. https://web.archive.org/web/20140912071628/ http://expo.se/www/download/sds_vitbok_Expo_2_2014. pdf (accessed on June 3, 2020).

- (2011). "Hot tömmer SD-stolar i kommunerna." Dagens Nyheter. Nov.9, 2011. https://www. dn.se/nyheter/sverige/hot-tommer-sd-stolar-i-kommunerna/ (accessed on June 8, 2020). 
- (2015). The Party Preference Survey in November 2015, Statistics Sweden, SCB. https:// www.scb.se/contentassets/a5d69f15a6a84882882ba37dle3d5f08/me0201_2015m05_br_me60br1501.pdf(accessed June 4, 2020).

- (2015). "Danish nationalists cheer Sweden Democrat poll." The Local. August 20, 2015, https://www.thelocal.se/20150820/denmarks-nationalists-rally-after-sweden-democrats-rise (accessed on June 8, 2020).

- (2017). "Europe's Growing Muslim Population." Pew Research Center. Nov. 29, 2017. https://www.pewforum.org/2017/11/29/europes-growing-muslim-population/ (accessed on June 5, 2020).

- (2017). "Statistik 2017 - Number of people served at registered religious congregations which are entitled to government support." Swedish Agency for Support to Faith Communities. https://www.myndighetensst.se/bidrag/organisationsbidrag/bidragsgrundande-statistik/statistik-2017.html (accessed on June 5, 2020).

— (2018). "Sifo: Majoritet vill förbjuda böneutrop." Göteborgs-Posten, March 16, 2018, https:/l www.gp.se/nyheter/sverige/sifo-majoritet-vill-förbjuda-böneutrop-1.5397262 (accessed on June 6,2020 ).

- (2018). Sweden's general election results in stalemate as far-right support surges." Deutsche Welle (DW), Sept. 10, 2018. https://www.dw.com/en/swedens-general-election-resultsin-stalemate-as-far-right-support-surges/a-45423940(accessed on June 3, 2020).

- (2018). Mottagandeutredningen - Ett ordnat mottagande: gemensamt ansvar för snabb etablering eller återvändande.Statens offentliga utredningar: SOU 2018:22. Stockholm: Arbetsmarknadsdepartementet.

— (2018). "Finns Party hails closer ties with nationalist Sweden Democrats." Yle. July 17, 2018. https://yle.fi/uutiset/osasto/news/finns_party_hails_closer_ties_with_nationalist_sweden_democrats/10313894 (accessed on June 8, 2020).

- (2019). Timbro Authoritarian Populism Index 2019. Timbro. https://populismindex.com/ wp-content/uploads/2019/02/TAP2019C.pdf (accessed on June 4, 2020).

- (2019). "Mainstream Swedish party open to working with once-spurned nationalists." The Financial Times. Dec.5, 2019. https://www.ft.com/content/1e692a28-1764-11ea-9ee411 f260415385 (accessed on June 8, 2020).

- (2019). "Brexit Softens Swedish Eurosceptic Parties' Stance." Country Report: Sweden, Economist Intelligence Unit (EIU), Sept 19, 2019.

- (2020). "Sweden Population 2020." World Population Review. https://worldpopulationreview.com/countries/sweden-population/ (accessed on June 5, 2020).

Abedi A. (2004). Anti-Political Establishment Parties: A Comparative Analysis. (London: Routledge).

Ahlander, Johan. (2019). "Populist Sweden Democrats ditch 'Swexit' ahead of EU elections." Reuters, Feb. 6, 2019. https://www.reuters.com/article/uk-sweden-politics-eu/populist-sweden-democrats-ditch-swexit-ahead-of-eu-elections-idUKKCN1PV28Q (accessed on June 2, 2020).

Andersson, J. (2009). "Nordic nostalgia and Nordic light: The Swedish model as Utopia 1930-2007." Scandinavian Journal of History, 34, 229-245.

Andersson, C. (2010). "Populism och journalistik-stadigt sällskap eller tillfällig bekantskap?" 
Statsvetenskaplig tidskrift. 112(3): 271-287.

Arzheimer, K. (2009). "Contextual factors and the extreme right vote in Western Europe, 1980-2002." American Journal of Political Science, 53, 259-275.

Arzheimer, K. (2018). "Explaining electoral support for the radical Right." In: J. Rydgren (ed.), The Oxford Handbook of the Radical Right, Oxford: Oxford University Press, pp. 143-165.

Aylott, Nicholas \& Bolin, Niklas. (2019). "A party system in flux: the Swedish parliamentary election of September 2018." West European Politics. http://www.diva-portal.org/smash/ get/diva2:1301277/FULLTEXT01.pdf (accessed June 1, 2020).

Åkesson, J. (2007). “Jimmy Åkessons tal inför riksårsmötet 2007. (Jimmy Åkesson's speech at the annual meeting 2007).

Åkesson, Jimmy. (2019). "SD: Därför ändrar vi vår EU-politik." Aftonbladet. Jan.31, 2019. https://www.aftonbladet.se/debatt/a/A2Kpyr/sd-darfor-andrar-vi-var-eu-politik (accessed on June 8, 2020).

Backlund, Anders. (2011). The Sweden Democrats in Political Space: Estimating policy positions using election manifesto content analysis. Master Thesis, Södertörn University, http:// www.diva-portal.org/smash/get/diva2:625421/FULLTEXTO2.pdf (accessed June 1, 2020).

Backlund, A. (2016). Isolation and Policy Co-optation: e Path Dependency of the Swedish Cordon Sanitaire, paper prepared for the annual conference of the Swedish Political Science Association (SWEPSA), Visby, October 19-21.

Backlund, Anders, and Jungar, Ann-Cathrine. (2019). "Populist Radical Right Party-Voter Policy Representation in Western Europe." Representation: Minding the Gap? Political Representation of Populist Parties, 55, no. 4. 393-413.

Barker, M. (1981). The New Racism. London: Junction.

Barmen, Viggo. (2019). Does Refugee Migration Make Right-wing Populists More Popular? Evidence from a Swedish Refugee Dispersal Program. Uppsala University, Master Thesis. http://www.diva-portal.org/smash/get/diva2:1335414/FULLTEXTO1.pdf (accessed June 1, 2020).

Bay, A.H., Strömblad, P., \& Bengtsson B. (2010). "An introduction to diversity, inclusion and citizenship in Scandinavia." In: B. Bengtsson, P. Strömblad, \& A.H. Bay (Eds.), Diversity, inclusion and citizenship in Scandinavia. Newcastle upon Tyne, UK: Cambridge Scholars Publishing.

Bengtsson, M.; Berglund, T. \& Oskarson, M. (2013). "Class and Ideological Orientations Revisited: An Exploration of Class-based Mechanisms." British Journal of Sociology. 64 (4): 697-716.

Benoit, K., \& Laver, M. (2006). Party Policy in Modern Democracies. London: Routledge.

Berezin, Mabel. (2013), "The Normalization of the Right in Post-Security Europe." Politics in the Age of Austerity, Polity Press, p. 255.

Berglund, Jenny. (2015). "Sweden's protests against Islamophobia highlight the polarized views of Swedish citizens toward Muslims." LSE EUROPP Blog. January 7, 2015. http://blogs. Ise.ac.uk/europpblog/2015/01/07/swedens-protests-against-islamophobia-highlight-the-polarised-views-of-swedish-citizens-toward-muslims/ (accessed on June 2, 2020).

Berlin I. (1976). Vico and Herder: Two Studies in the History of Ideas, London: Hogarth. 
Betz, H. G. (2004). Exclusionary Populism in Western Europe in the 1990s and Beyond: A Threat to Democracy and Civil Rights? Identities, Conflict and Cohesion. Paper 9 (Geneva: United Nations Research Institute for Social Development).

Betz, H.G. \& Meret, S. (2009). "Revisiting Lepanto: The political mobilization against Islam in contemporary Western Europe." Patterns of Prejudice, 43, 313-334.

Bhambra, G. (2017). "Locating Brexit in the pragmatics of race, citizenship and empire." In: W. Outhwaite (ed.). Brexit: Sociological Responses, London: Anthem Press, pp. 91-100.

Bjereld, Ulf; Karin Eriksson \& Jonas Hinnfors. (2016). Förhandla eller dö. Decemberöverenskommelsen och svenska demokrati i förändring. Stockholm: Atlas.

Bolin, Niklas. (2018). "Det nya svenska partisystemet." In: Lars Nord, Marie Grusell, Niklas Bolin, and Kajsa Falasca (eds.). Snabbtänkt. Reflektioner om valet 2018 av ledande forskare. Sundsvall: Mid Sweden University.

Bolin, Niklas \& Aylott, Nicholas. (2019). "Right-Wing Populist Party Leadership in Sweden: One of a Kind or one of the Crowd?" Polish Political Science Review. Vol. 7, no 1, p. 24-40.

Brandel, Tobias. (2010). "SD siktar in sig på hbt-röster." Svenska Dagbladet. July 27, 2010. https://www.svd.se/sd-siktar-in-sig-pa-hbt-roster (accessed on June 7, 2020).

Brubaker, R. (2017). "Between nationalism and civilizationism: the European populist moment in comparative perspective." Ethnic and Racial Studies. 40(8): 1191-1226.

Castells, M. (1993). "European Cities, the Informational Society and the Global Economy." Journal of Economic Social Geography. 84(4): 475-85.

Christodoulou, Loukas. (2014). "Will the Sweden Democrats stay isolated?" Radio Sweden, Sept. 15, 2014.https://sverigesradio.se/sida/artikel.aspx?programid=2054\&artikel=5965660 (accessed on June 4, 2020).

Cochrane, C., \& Nevitte, N. (2014). "Scapegoating: Unemployment, far-right parties and anti-immigrant sentiment." Comparative European Politics. 12, 1-32.

Dahlström, C. \& P. Esaiasson. (2011). "The Immigration Issue and Anti-immigrant Party Success in Sweden 1970-2006: A Deviant Case Analysis." Party Politics. 19:2, 343-364.

Declair, E.G. (1999). Politics on the Fringe: The People, Policies, and Organization of the French National Front. Durham, NC and London: Duke University Press.

Dehdari, Sirus Håfström. (2018). Radical Right, Identity, and Retaliation, Stockholm University, Faculty of Social Sciences, Department of Economics. Doctoral Thesis, http://www. diva-portal.org/smash/get/diva2:1198518/FULLTEXT01.pdf (accessed on June 3, 2020).

Deland, Mats; Fredrik Hertzberg \& Thomas Hvitfeldt. (2010). "Introduction." In: Det Vita Fältet: Samtida Forskning om Högerextremism. Edited by Mats Deland, Fredrik Hertzberg, and Thomas Hvitfeldt, 5-13. Uppsala: University of Uppsala Department of History.

Demker, Marie. (2015). "Mobilisering kring migration förändrar det svenska partisystemet." In: Fragment: SOM-undersökningen 2014, ed. B. Johansson, M. Oskarson, H. Oscarsson, and A. Bergström. SOM-institutet: Göteborg.

Demker, M. \& S. van der Meiden. (2016). "Allt starkare polarisering och allt lägre yktingmotstånd." In: Ekvilibrium: SOM-undersökningen 2015, ed. J. Ohlsson, H. Oscarsson and M. Solevid. SOM-insitutet: Göteborg. 
Downs, William M. (2012). Political Extremism in Democracies: Combating Intolerance. Palgrave Macmillan, pp. 33, 149.

Eger, Maureen \& Hjerm, Mikael. (2018). "The Sweden Democrats remain deeply unpopular despite making gains." Open Democracy, Sept. 7, 2018. https://www.opendemocracy.net/ en/sweden-democrats-support-hit-electoral-ceiling/ (accessed on June 2, 2020).

Ekman, Ivar. (2018). "Swedish Unexceptionalism." Foreign Affairs, Sept. 10, 2018. https:// www.foreignaffairs.com/articles/sweden/2018-09-10/swedish-unexceptionalism (accessed on May 31, 2020).

Ekman, Mattias. (2015). "Online Islamophobia and the Politics of Fear: Manufacturing the Green Scare." Ethnic and Racial Studies. 38:11, 1986-2002.

Ekman, Mikael \& Daniel Poohl. (2010). Ut ur Skuggan: En Kritisk Granskning av Sverigedemokraterna. Stockholm: Natur \& Kultur.

Elgenius, G. \& Rydgren, J. (2017). "The Sweden democrats and the ethno-nationalist rhetoric of decay and Betrayal." Special Issue: what is going on in Sweden? Journal of the Swedish Sociological Association (Sociologisk Forskning).54(4): 353-358.

Elgenius, Gabriella, and Jens Rydgren. (2019). "Frames of Nostalgia and Belonging: The Resurgence of Ethno-nationalism in Sweden." European Societies: The Far Right as Social Movement, 21, no. 4: 583-602.

Ellinas, A.A. (2010). The Media and the Far Right in Western Europe: Playing the Nationalist Card. New York: Cambridge University Press.

Gardell, Mattias \& Muftee, Mehek. (2018). "Islamophobia in Sweden - National Report 2017." SETA. http://www.islamophobiaeurope.com/wp-content/uploads/2018/04/Sweden.pdf (accessed on June 7,2020$)$.

Gasslander, T. (2015). "Uniformerade nazister deltog i SD-demonstration mot flyktingar." EXPO. Oct. 19, 2015. https://expo.se/2015/10/uniformerade-nazister-deltog-i-sd-demonstration-mot-flyktingar (accessed on June 4, 2020).

Golder, M. (2003). "Explaining variation in the success of extreme right parties in Western Europe." Comparative Political Studies. 36, 432-466.

Griffin, Roger. (1993). The Nature of Fascism. Psychology Press.

Griffin, R. (2000). "Interregnum or endgame? Radical right thought in the 'post-fascist' era." Journal of Political Ideologies. 5(2): 163-178.

Hagberg, Sebastian. (2017). Mätning: SD dominerar stort i sociala medier, Sifo. March 26, 2017.

Hainmueller, J. \& Hiscox, M.J. (2007). "Educated Preferences: Explaining Attitudes Toward Immigration in Europe." International Organization. 61: 399-442.

Hall, P. (1998). The Social Construction of Nationalism: The Case of Sweden. Lund: Lund University Press.

Hamidi-Nia, Gilda. (2019). "KD-ledaren öppnar för SD-samarbete." SVT, March 21, 2019. https://www.svt.se/nyheter/inrikes/kd-ledaren-oppnar-for-sd-samarbete (accessed on June 4, 2020).

Hamrud, Annika. (2006). "Regeringen har inte varit inblandad." Dagens Nyheter. Feb.10, 
2006. https://www.dn.se/nyheter/sverige/regeringen-har-inte-varit-inblandad/ (accessed on June 7, 2020).

Heinö, Andreas Johansson. (2016). "Timbro Authoritarian Populism Index 2016." Timbro. Juni 29, 2016. https://timbro.se/allmant/timbro-authoritarian-populism-index-2016/ (accessed May 31, 2020).

Hellström, Anders \& Tom Nilsson. (2010). "'We Are the Good Guys': Ideological Positioning of the Nationalist Party Sverigedemokraterna in Contemporary Swedish Politics." Ethnicities. 10, no. 1: 55-76.

Hellström, A., Nilsson, T., \& Stoltz, P. (2012). "Nationalism vs. nationalism: e challenge of the Sweden democrats in the Swedish public debate." Government \& Opposition, 47, 186-205.

Holender, Robert \& Svahn, Clas. (2006). "Muhammedteckningar borta efter Säposamtal." Dagens Nyheter. Feb.10, 2006. https://www.dn.se/nyheter/sverige/muhammedteckningar-borta-efter-saposamtal/ (accessed on June 7, 2020).

Holmberg, S. (2007). "Sverigedemokrater - vilka är dom och vad vill dom?" In: S. Holmberg \& L. Weibull (Eds.), Det nya Sverige. Göteborg, Sweden: Göteborgs universitet, SOM-institutetet.

Holmberg, S.; Näsman, P.; \& Wänström, K. (2010). Riksdagsvalet 2010, SVT valundersökning.

Holmberg, S. \& H. Oscarsson. (2004). Väljare: Svenskt väljarbeteende under 50 år. Stockholm: Norstedts Juridik.

Holmes D. R. (2000). Integral Europe: Fast-Capitalism, Multiculturalism, Neofascism. Princeton, NJ: Princeton University Press.

Ivarsflaten, E. (2008). "What Unites Right-wing Populists in Europe? Re-Examining Grievence Mobilization models in Seven Successful Cases." Comparative Political Studies, 41(3): 3-23.

Jansen, G., G. Evans, and N.D.D. Graad. (2012). "Class-Voting and Left-Right Party Positions: A Comparative Study of 15 Western Democracies, 1960-2005." Social Science Research. 42: $376-400$

Janhunen, Pontus. (2006). "Centerpartist polisanmäler Sverigedemokraterna." Dagens Nyheter. Feb.14, 2006. https://web.archive.org/web/20121015082955/http://www.dn.se/nyheter/ politik/centerpartist-polisanmaler-sverigedemokraterna (accessed on June 7, 2020).

Jungar A. and Jupskås A. (2014) "Populist radical right parties in the Nordic region: A new and distinct party family?" Scandinavian Political Studies, 37: 215-238.

Kaati, Lisa et al. (2017). Det vita hatet: radikal nationalism i digitala miljöer. Stockholm: FOI, Nov. 2017, FOI- R-4463-SE.

Kallis, A. (2018). "The radical right and Islamophobia." In: J. Rydgren (ed.), The Oxford Handbook of the Radical Right,Oxford: Oxford University Press, pp. 42-60.

Ketola, Markus \& Nordensvärd, Johan. (2012). Euroscepticism as political opportunity. Comparing the Euroscepticism of the Finnish and Swedish populist parties. UACES 42nd Annual Conference Passau, Sept. 3-5, 2012. https://www.uaces.org/documents/papers/1201/ ketola.pdf (accessed on June 2, 2020).

Kihlström, Staffan. (2006). "Säpo försvarar beslut att stänga SD-sajt." Dagens Nyheter. Feb.10, 2006. https://www.dn.se/nyheter/sverige/sapo-forsvarar-beslut-att-stanga-sd-sajt/ 
(accessed on June 7, 2020).

Kinberg Batra, Anna; Annie Lööf; Jan Björklund \& Göran Hägglund. (2014). "Med nya regler kan vi göra minoritetsregerande möjligt." Dagens Nyheter. Dec.9, 2014. https://www.dn.se/ debatt/med-nya-regler-kan-vi-gora-minoritetsregerande-mojligt/ (accessed on June 8, 2020).

Kitschelt, Herbert. (1995). The Radical Right in Western Europe. A Comparative Analysis. Ann Arbor: University of Michigan Press.

Kitschelt, H. (2012). "Social Class and the Radical Right: Conceptualizing Political Preference Formation and Partisan Choice." In: Class Politics and the Radical Right, ed. J. Rydgren. London: Routledge.

Klingemann H.D.; Volkens A.; Bara J.; Budge I. \& McDonald M.D. (2006). Mapping Policy Preferences II: Estimates for Parties, Electors, and Governments in Eastern Europe, European Union and OECD 1990-2003. Oxford: Oxford University Press.

Kriesi H.; Grande E.; Lachat R.; Dolezal M.; Bornschier S. \& Frey T. (2006). "Globalization and the Transformation of the National Political Space: Six European Countries Compared." European Journal of Political Research. 45 (6): 921-956.

Kriesi, H.; Grande, E.; Lachat, R.; Dolezal, M.; Bornschier, S. \& Frey, T. (2008). West European Politics in the Age of Globalization, Cambridge: Cambridge University Press.

Krzyzanowski, M.; P. Ledin \& J. Rydgren. (2016). Swedish Socio-Cultural Politics, Discursive Shifts, and the Refugee Crisis. Paper Presented at the Mediatisation and Politicisation of Refugee Crisis in Europe Workshop, European University Institute, Florence, 27 April 2016.

Larsson, S. and M. Ekman. (2001). Sverigedemokraterna: den nationella rörelsen (The Sweden Democrats: The national movement). Stockholm: Ordfront Förlag.

Larsson, B. (2015). "Facklig anslutning år 2015. Facklig anslutning bland anställda efter klass och kön år 1990-2015." Arbetslivsenheten, LO.

Letmark, Peter. (2006). "Fritt fram för Sverigedemokraterna att annonsera." Dagens Nyheter. June 16, 2006. https://www.dn.se/kultur-noje/fritt-fram-for-sverigedemokraterna-attannonsera/ (accessed on June 9, 2020).

Loxbo, K. (2014). "Voters' Perceptions of Policy Convergence and the Short-term Opportunities of Anti-immigrant Parties: Examples from Sweden." Scandinavian Political Studies, 37: 239-262.

Loxbo, K. (2015). "En förklaring till Sverigedemokraternas framgångar i riksdagsvalet 2014." Statsvetenskaplig tidskris.117:2, 169-187.

Mair, P. (2002). "Populist Democracy vs Party Democracy." In: Y. Meny (ed.) Democracies and the Populist Challenge, pp. 81-98, Gordonsville: Palgrave Macmillan.

Mehic, Adrian. (2019). Immigration and Right-Wing Populism: Evidence from a Natural Experiment. Department of Economics Working Paper Series 2019:5. Lund University, Department of Economics.

Mellgren, Fredrik. (2013). "Granskningsnämnden: Tillåtet att kalla SD främlingsfientligt." Svenska Dagbladet. June 12, 2013. https://www.svd.se/granskningsnamnden-tillatet-att-kalla-sd-framlingsfientligt (accessed on June 8, 2020).

Miles, R. (1989). Racism. London: Routledge. 
Minkenberg, M. (1997). "The new right in France and Germany: Nouvelle Droite, Neue Rechte and the new right radical parties." In: P.H. Merkl \& L. Weinberg (eds), The revival of right-wing extremism in the nineties. London: Frank Cass.

Minkenberg, M. (2018). "Religion and the radical right." In: J. Rydgren (ed.), The Oxford Handbook of the Radical Right, Oxford: Oxford University Press, pp. 366-393.

Montelius, Martina. (2017). "Homonationalism - det rosa kriget." Expressen. April 14, 2017. https://www.expressen.se/kultur/homonationalism-det-rosa-kriget/ (accessed on June 7, 2020).

Mouffe, C. (2005) On the Political. London: Routledge.

Mudde, Cass (2007). Populist Radical Right Parties in Europe. Cambridge: Cambridge University Press.

Mudde, Cass \& Kaltwasser, C. R. (2012). Populism in Europe and the Americas: Threat or corrective for democracy? Cambridge: Cambridge University Press.

Mulinari, Diana; Anders Neergaard; Gail Lewis, and Madeleine Kennedy-Macfoy. (2014). "We Are Sweden Democrats Because We Care for Others: Exploring Racisms in the Swedish Extreme Right." European Journal of Women's Studies,21, no. 1: 43-56.

Mulinari, Diana, \& Neergaard, Anders. (2014). "We are Sweden Democrats because we care for others: Exploring racisms in the Swedish extreme right." European Journal of Women's Studies, 21, 43-56.

Müller, Tim; Hedström, Peter; Valdez, Sarah; and Wennberg, Karl. (2016). Right-wing populism and social distance towards Muslims in Sweden - Results from a nation-wide vignette study. Linköping University, http://www.diva-portal.org/smash/get/diva2:778393/FULLTEXTO2.pdf (accessed on June 2, 2020).

Naib, Fatima. (2015). "Sweden far-right plans gay parade in mainly Muslim area." Al Jazeera. July 29, 2015. https://www.aljazeera.com/news/2015/07/sweden-farright-plans-gay-pridemuslim-area-lgbt-150728180328656.html(accessed on June 7, 2020).

Napier J.L. \& Jost J.T. (2008). "The 'Anti-Democratic Personality' Revisited: A Cross-National Investigation of Working-Class Authoritarianism." Journal of Social Issues. 64 (3): 595-617.

Norocel, Ov Cristian. (2017). "Åkesson at Almedalen: Intersectional Tensions and Normalization of Populist Radical Right Discourse in Sweden." NORA - Nordic Journal of Feminist and Gender Research, 25, no. 2: 91-106.

Norris, P. (2005). Radical right: Voters and parties in the electoral market. Cambridge, UK: Cambridge University Press.

Odmalm, P. (2011). Political Parties and 'The Immigration Issue': Issue Ownership in Swedish Parliamentary Elections 1991-2010." West European Politics. 34(5): 1070-1091.

Oesch, Daniel. (2008). "Explaining Workers' Support for Right-wing Populist Parties in Western Europe: Evidence from Austria, Belgium, France, Norway and Switzerland." International Political Science Review. 29 (3): 349-373.

Orrenius, Niklas. (2014). "Den leende nationalismen." Dagens Nyheter. Dec.14, 2014. https:// www.dn.se/nyheter/politik/den-leende-nationalismen/ (accessed on June 8, 2020).

Oskarson, Maria, and Marie Demker. (2015). "Room for Realignment: The Working-Class Sympathy for Sweden Democrats." Government and Opposition, 50, no. 4: 629-51. 
Pettersson, Katarina; Karmela Liebkind, \& Inari Sakki. (2016). "You Who Are an Immigrant Why Are You in the Sweden Democrats?" Discourse \& Society. 27. no.6: 624-41.

Peterson, A. (2016) "The institutionalization processes of a neo-Nazi movement party: securing movement outcomes." In: L. Bosi, M. Gugni and K. Uba (eds.), The Consequences of Social Movements, Cambridge: Cambridge University Press, pp. 314-338.

Pettersson, Katarina; Karmela Liebkind, and Inari Sakki. (2016). "'You Who Are an Immigrant - Why Are You in the Sweden Democrats?"” Discourse \& Society, 27, no. 6: 624-41.

Radosevich, Frank. (2018). "Sweden Democrat MEP candidate: More money for EU border system." sverigesradio.se.May 9, 2018. https://sverigesradio.se/sida/artikel.aspx?programid=2054\&artikel=7214581 (accessed on June 8, 2020).

Raunio, Tapio. (2007). "Softening but Persistent: Euroscepticism in the Nordic EU Countries." Acta Politica. 42. 10.1057/palgrave.ap.5500183.

Rothstein, Bo. (2014). "The End of Swedish Exceptionalism." Foreign Affairs, September 18, 2014. https://www.foreignaffairs.com/articles/sweden/2014-09-18/end-swedish-exceptionalism (accessed on May 31, 2020).

Rothwell, James. (2018). "How the far-right Sweden Democrats could be kingmakers after this weekend's election". The Telegraph. Sept. 4, 2018. https://www.telegraph.co.uk/politics/2018/09/04/sweden-elections-everything-need-know/(accessed on June 3, 2020).

Rydgren, Jens. (2002) 'Radical right populism in Sweden: still a failure, but for how long?', Scandinavian Political Studies. 25(1): 27-56.

Rydgren, J. (2003). The Populist Challenge - Political Protest and Ethno-Nationalist Mobilization in France. New York and Oxford: Berghahn Books.

Rydgren, Jens (2006). From Tax Populism to Ethnic Nationalism: Radical Right-wing Populism in Sweden. Oxford: Berghahn Books. pp. 108-113. ISBN 1-84545-218-6.

Rydgren, J. (2007). "The Sociology of the Radical Right." Annual Review of Sociology. 33: 241-62.

Rydgren, J. (2008). "Immigration sceptics, xenophobes or racists? Radical right-wing voting in six West European countries." European Journal of Political Research, 47, 737-765.

Rydgren, J. (2010). "Radical Right-Wing Populism in Denmark and Sweden: Explaining Party System Change and Stability." The SAIS Review of International Affairs, 30(1): 57-71.

Rydgren, J. (2018). "The Radical Right: An introduction." In: Jens Rydgren (ed), The Oxford Handbook of the Radical Right. New York: Oxford university Press.

Rydgren, Jens \& van der Meiden, Sara. (2019). "The radical right and the end of Swedish exceptionalism." Eur Polit Sci, 18. 439-455.

Sannerstedt, A. (2008). "De okända väljarna - en analys av de skånska väljare som röstade på icke riksdagspartier 2006" (The unknown voters - An analysis of the electorate in Skåne that voted for non-parlamentary parties in 2006), in L. Nilsson and R. Antoni (eds) Medborgarna, regionen och flernivådemokratin, pp. 49-70. Göteborg: SOM-insitutet.

Sartori, Giovanni. (2005). Parties and Party Systems: A Framework for Analysis. Colchester: ECPR Press. 
Schultheis, Emily. (2018). "Sweden's Far Right Has Won the War of Ideas." Foreign Policy. Sept.10, 2018. https://foreignpolicy.com/2018/09/10/swedens-nazi-offspring-won-the-war-ofideas/ (accessed on June 7, 2020).

Skodo, Admir. (2018). Sweden: By Turns Welcoming and Restrictive in its Immigration Policy. Migration Policy Institute, Dec. 6, 2018. https://www.migrationpolicy.org/article/sweden-turns-welcoming-and-restrictive-its-immigration-policy(accessed on June 4, 2020).

Steiner, Kristian. (2014). "Images of Muslims and Islam in Swedish Christian and Secular News." Discourse." Media, War \& Conflict, p. 1-26 http://www.diva-portal.org/smash/get/ diva2:1398469/FULLTEXT01.pdf (accessed on June 2, 2020).

Sköld, Josefin. (2010). "Invandrare - och Sverigedemokrat." Aftonbladet. May 24, 2010. https://www.aftonbladet.se/nyheter/a/oRkwn7/invandrare-och-sverigedemokrat (accessed on June 8, 2020).

Strömblad, Per \& Bo Malmberg. (2016). "Ethnic Segregation and Xenophobic Party Preference: Exploring the Influence of the Presence of Visible Minorities on Local Electoral Support for the Sweden Democrats." Journal of Urban Affairs, 38, no. 4: 530-45.

Sweden Democrat (SD) election and party manifestos and other relevant literature SD Party and Election Manifestos 1989, 1994, 1996; 1999; 2014.

Taggart P. A. (1996). The New Populism and the New Politics: New Protest Parties in Sweden in a Comparative Perspective. Basingstoke: Palgrave Macmillan.

Tamas, G. (2003). Lasermannen: en berättelse om Sverige (The Laser Man: A story of Sweden). Stockholm: Ordfront Förlag.

Teitelbaum, Benjamin (2013). Come Hear Our Merry Song: Shifts in the Sound of Contemporary Swedish Radical Nationalism. Ph.D. Dissertation, Brown University. pp. 242-265.

Teitelbaum, Benjamin R. (2013). Come Hear Our Merry Song: Shifts in the Sound of Contemporary Swedish Radical Nationalism. Ph.D. Dissertation, Brown University. pp. 242-265.

Teitelbaum, Benjamin. (2018). "Missing Links: Politics and the Misrecognition of the Sweden Democrats." Scandinavian - Canadian Studies. 25: 50.

Volkens, A. (2007). "Strengths and weaknesses of approaches to measuring policy positions of parties." Electoral Studies. 26(1), 108-120.

Wendt, M. (2012). Politik som spektakel: Almedalen, mediemakten och den svenska demokratin (Politics as spectacle: Almedalen, the power of media and the Swedish democracy). Stockholm: Atlas.

Wernersson, Annie. (2017). "SD ökar kraftigt bland väljare med utländsk bakgrund." SVT. June 7, 2017. https://www.svt.se/nyheter/inrikes/sd-okar-kraftigt-bland-utrikes-fodda (accessed on June 8,2020$)$.

Westlind, D. (1996). The Politics of Popular Identity: Understanding Recent Populist Movements in Sweden and the United States. Lund: Lund Political Studies.

Widfeldt, A. (2000). "Scandinavia: mixed success for the populist right." Parliamentary Affairs. 53(3): 486-500.

Widfeldt, A. (2015), Extreme Right Parties in Scandinavia, (London: Routledge).

Widfeldt, Anders (2010), "A fourth phase of the extreme right? Nordic immigration-critical 
parties in a comparative context." NORDEUROPAforum (1/2): 7-31. https://edoc.hu-berlin.de/ handle/18452/8689 (accessed on June 3, 2020).

Zaslove, Andrej. (2004). "Closing the door? The ideology and impact of radical right populism on immigration policy in Austria and Italy." Journal of Political Ideologies. 9(1): 99-118. 


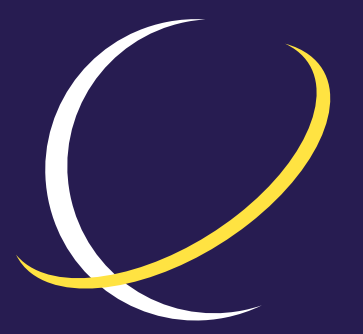

\section{ECPS \\ EUROPEAN CENTER for POPULISM STUDIES}

\section{ABOUT ECPS}

The European Center for Populism Studies (ECPS) is an independent, nonpartisan, nonprofit organization, based in Brussels, for research on and analysis of challenges posed by the resurgence of political populism. ECPS facilitates collaboration among networks of academic experts, practitioners, policymakers, media, and other stakeholders. ECPS offers a platform for the exchange of policy solutions on issues relating to rising populism and provides insights for policy-making and critical analysis to raise broader awareness and engagement through:

\section{Publications}

\section{Academic publications}

Policy reports

White papers

Commentaries

Podcasts and interviews with experts

Events, seminars, workshops, and conferences

\section{Research Programs}

Authoritarianism

Digital Populism

Economics

Environment \& Climate

Extremism \& Radicalisation

\section{Gender}

Human Rights

Foreign Policy

Leadership \& Persona

Migration

\section{ECPS Youth Program}

ECPS Academy 